\title{
Enantioenriched Positive Allosteric Modulators Display Distinct Pharmacology at the Dopamine $D_{1}$ Receptor
}

\author{
Tim J. Fyfe ${ }^{1}$, Peter J. Scammells ${ }^{1}$, J. Robert Lane ${ }^{2,3, *}$ and Ben Capuano ${ }^{1, *(D)}$ \\ 1 Medicinal Chemistry, Monash Institute of Pharmaceutical Sciences, Monash University, 381 Royal Parade, \\ Parkville, VIC 3052, Australia; tim.fyfe@griffithhack.com (T.J.F.); peter.scammells@monash.edu (P.J.S.) \\ 2 Drug Discovery Biology, Monash Institute of Pharmaceutical Sciences, Monash University, 381 Royal Parade, \\ Parkville, VIC 3052, Australia \\ 3 School of Life Sciences, Queen's Medical Centre, University of Nottingham, Nottingham NG7 2UH, UK \\ * Correspondence: Rob.Lane@nottingham.ac.uk (J.R.L.); ben.capuano@monash.edu (B.C.)
}

Citation: Fyfe, T.J.; Scammells, P.J.;

Lane, J.R.; Capuano, B.

Enantioenriched Positive Allosteric Modulators Display Distinct Pharmacology at the Dopamine $\mathrm{D}_{1}$ Receptor. Molecules 2021, 26, 3799. https://doi.org/10.3390/

molecules26133799

Academic Editor: Jianguo Fang

Received: 26 May 2021

Accepted: 17 June 2021

Published: 22 June 2021

Publisher's Note: MDPI stays neutral with regard to jurisdictional claims in published maps and institutional affiliations.

Copyright: (c) 2021 by the authors. Licensee MDPI, Basel, Switzerland. This article is an open access article distributed under the terms and conditions of the Creative Commons Attribution (CC BY) license (https:// creativecommons.org/licenses/by/ $4.0 /)$.

\begin{abstract}
Background: Two first-in-class racemic dopamine $D_{1}$ receptor $\left(D_{1} R\right)$ positive allosteric modulator (PAM) chemotypes (1 and 2) were identified from a high-throughput screen. In particular, due to its selectivity for the $D_{1} R$ and reported lack of intrinsic activity, compound 2 shows promise as a starting point toward the development of small molecule allosteric modulators to ameliorate the cognitive deficits associated with some neuropsychiatric disease states; (2) Methods: Herein, we describe the enantioenrichment of optical isomers of 2 using chiral auxiliaries derived from $(R)$ - and (S)-3-hydroxy-4,4-dimethyldihydrofuran-2(3H)-one (D- and L-pantolactone, respectively); (3) Results: We confirm both the racemate and enantiomers of 2 are active and selective for the $D_{1} R$, but that the respective stereoisomers show a significant difference in their affinity and magnitude of positive allosteric cooperativity with dopamine; (4) Conclusions: These data warrant further investigation of asymmetric syntheses of optically pure analogues of 2 for the development of $D_{1} R$ PAMs with superior allosteric properties.
\end{abstract}

Keywords: dopamine $\mathrm{D}_{1}$ receptor; positive allosteric modulator; PAM; G protein-coupled receptors; synthetic medicinal chemistry; pharmacological evaluation; enantioenriched; chiral auxiliary; cAMP BRET

\section{Introduction}

Schizophrenia (SCZ) is a debilitating neuropsychiatric illness characterised by three distinct symptoms domains [1,2]. Positive symptoms describe manifestations of psychosis such as delusions, whereas negative symptoms are defined as alterations in drive and volition [3]. Cognitive deficits are a central feature of SCZ, and include deficits in working memory, attention, learning, and executive functioning [4]. Numerous studies have demonstrated an association between the severity of cognitive impairment and functional, social, and occupational outcomes in SCZ. Thus, the development of therapeutics that address this symptom domain are desirable [5]. Unfortunately, current clinical antipsychotic drugs (APDs) fail to address these cognitive symptoms [6,7].

Hypodopaminergic function in the dorsolateral prefrontal cortex (dlPFC), an area associated with cognitive control and executive functions including working memory and selective attention [8], is thought to be related to negative symptoms and cognitive deficits [9,10]. Indeed, both dopamine receptor (DR) antagonists and dopamine (DA) depletion in the dlPFC impair cognitive function [11-13]. There is mounting evidence to suggest that $D_{1} R$ agonists can reverse these deficits [14,15], although excessive $D_{1} R$ stimulation may impede cognitive function $[16,17]$. Many orthosteric $D_{1} R$ agonists that compete with DA for the orthosteric binding site display a lack of subtype selectivity (relative to other DRs) as well as poor pharmacokinetic properties. The benzazepine class of $\mathrm{D}_{1} \mathrm{R}$ agonists have poor bioavailability [18] and has the propensity to lower seizure 
thresholds [19]. Similarly, the $\mathrm{D}_{1} \mathrm{R}$ agonist dihydrexidine displays poor oral bioavailability and is rapidly metabolised in vivo [20]. Orthosteric $D_{1} R$ agonists have also been shown to increase incidence of drug-induced hypotension, potentially mediated by $\mathrm{D}_{1}$ Rs expressed in the periphery [21], as well as a rapid acquisition of tolerance [22,23]. There is clearly an unmet need for the development of selective, bioavailable small molecule $\mathrm{D}_{1} \mathrm{R}$ ligands to further interrogate their potential utility to treat cognitive deficits associated with SCZ.

There has been tremendous recent progress in the development of novel $D_{1} R$ positive allosteric modulators (PAMs) [24-29] in concert with X-ray crystal [30] and cryo-EM structures $[31,32]$ that have revealed fascinating structural insights into the therapeutic potential of the $D_{1} R$. This has culminated in the clinical evaluation of the first $D_{1} R$ PAM LY3154207 (Mevidalen) [33] which is currently in phase 2 for the amelioration of cognition associated with Lewy body dementias. PAMs represent an alternative approach to targeting the $D_{1} R$ and act to modulate the affinity and/or efficacy of DA from a topographically distinct but conformationally linked binding site. The engagement of a less conserved allosteric binding site may confer greater subtype selectivity than orthosteric $\mathrm{D}_{1} \mathrm{R}$ agonists. $A \mathrm{D}_{1} \mathrm{R}$ PAM that displays positive allosteric cooperativity but lacks intrinsic efficacy which, in its own right, might maintain the temporal and spatial patterns of DA neurotransmission [34,35].

Lewis et al. recently identified two racemic $\mathrm{D}_{1} \mathrm{R}$ PAM chemotypes (Compound $\mathrm{A},(\mathbf{1})$ and Compound B, (rac-2), Figure 1) [36]. 1 was shown to be a $D_{1} R$ PAM but also acted as an agonist at the $D_{2} R$ and thus was not investigated further. As $D_{2} R$ agonism is known to exacerbate the positive symptoms of $S C Z$, achieving selectivity for the $D_{1} R$ versus the $D_{2} R$ is paramount for the development of efficacious cognitive-enhancing therapeutics. rac-2 was shown to have superior potency compared to 1 whilst being selective for the human $D_{1} R$. To our knowledge there is no reported chemical synthesis and biological characterisation of optical isomers of 2 . Herein, we report the synthesis and pharmacological characterisation of (rac)-2, and enantioenriched optical isomers of $\mathbf{2}$ (herein denoted as (S)-2 and (R)-2). These enantioenriched samples were accessed by employing various chiral auxiliaries in an asymmetric Diels Alder (ADA) cycloaddition reaction.

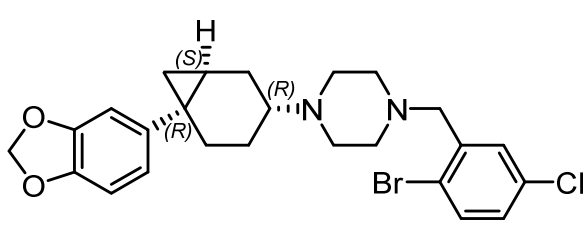

Compound A (1) $($ rel-1S,3R,6R)

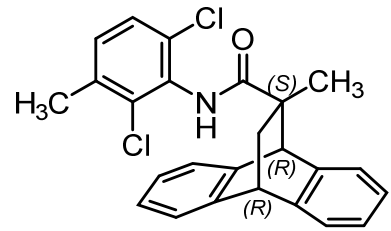

Compound B (2) $($ rel-9R,10R,12S)

Figure 1. High-throughput screening hits racemic Compound A [1-((rel-1S,3R,6R)-6(benzo[ $d][1,3]$ dioxol-5-yl)bicyclo [4.1.0]heptan-3-yl)-4-(2-bromo-5-chlorobenzyl)piperazine] (1) and racemic Compound B [rel-(9R,10R,12S)-N-(2,6-dichloro-3-methylphenyl)-12-methyl-9,10-dihydro9,10-ethanoanthracene-12-carboxamide] (rac-2) reported by Lewis et al. [36].

To characterise their pharmacology, we applied analytical pharmacological methods to determine allosteric ligand affinity for the unoccupied receptor, the strength of modulatory effects upon DA activity as well as the magnitude of allosteric agonism [37]. We demonstrate that enantiomers of $\mathbf{2}$ can be accessed in moderate enantiopurity in four synthetic steps. Importantly we reveal that these enantiomers display different affinities for the $\mathrm{D}_{1} \mathrm{R}$ as well as different levels of positive cooperativity with DA. The degree of allosteric cooperativity required for a 'clinical' $\mathrm{D}_{1} \mathrm{R}$ PAM is currently unknown. These data illustrate the importance of characterising optically pure analogues for future structure-activity relationship studies of 2 . 


\section{Results and Discussions}

\subsection{Chemistry}

Compound rac-2 was resynthesised in three steps according to Scheme 1 [38]. Firstly, $\mathrm{AlCl}_{3}$-catalysed Diels-Alder [4 +2]cycloaddition of methyl methacrylate 3 with anthracene 4 afforded the 9,10 bridged ester 5 as a racemic mixture. Ester saponification was achieved under forcing conditions with $\mathrm{NaOH}$ in THF $/ \mathrm{H}_{2} \mathrm{O}$ at reflux, affording acid 6. Subsequent treatment with thionyl chloride and DMF, followed by DMAP-catalysed nucleophilic substitution with commercially available 2,6-dichloro-3-methylaniline (7) afforded rac-2. High-performance liquid chromatography (HPLC) using an amylose chiral stationary phase (CSP) verified the presence of two enantiomers (see Supplementary Materials).
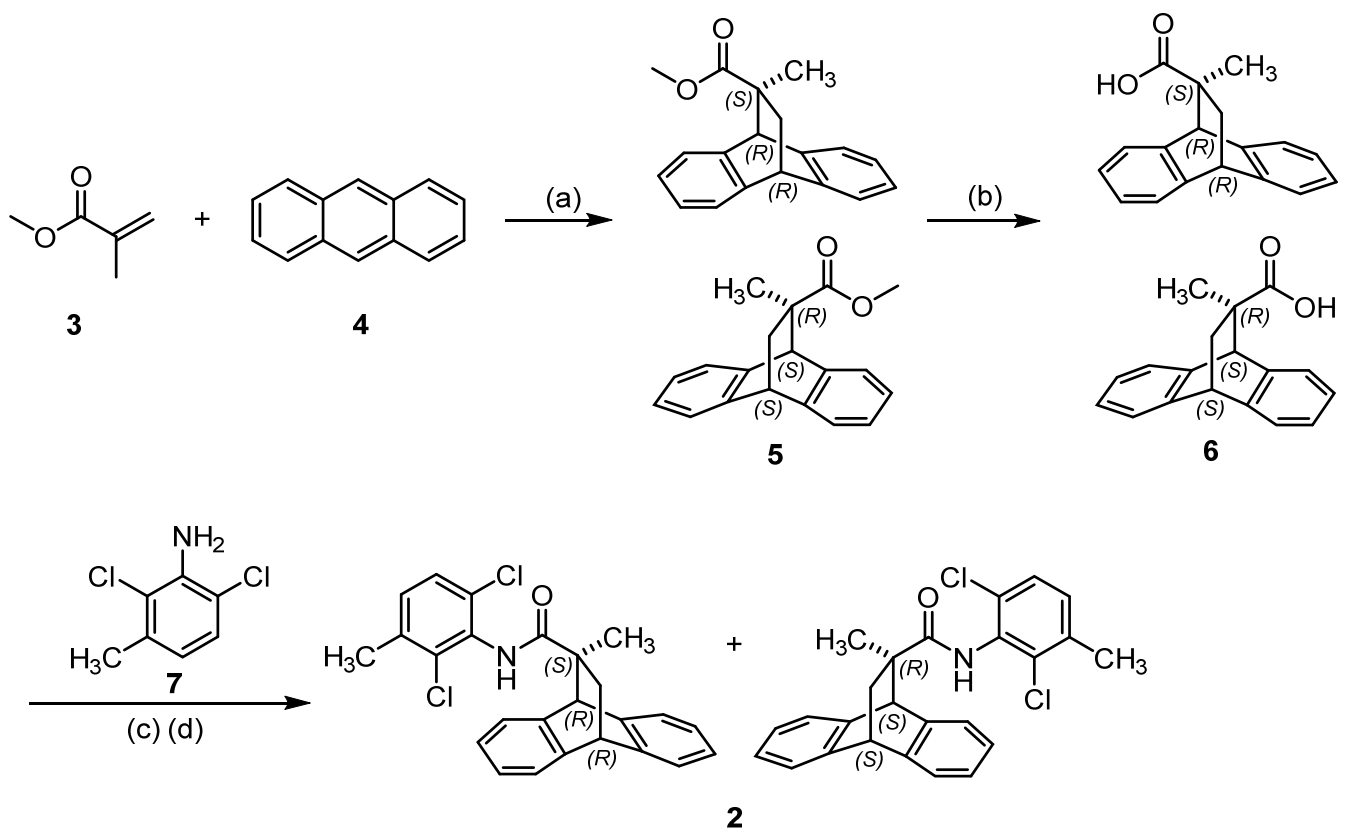

Scheme 1. Chemical synthesis of rac-2. Reagents and conditions: (a) $\mathrm{AlCl}_{3}, \mathrm{CH}_{2} \mathrm{Cl}_{2}$, r.t. $72 \mathrm{~h}, 63 \%$; (b) $\mathrm{NaOH}, 1: 1 \mathrm{THF} / \mathrm{H}_{2} \mathrm{O}$,

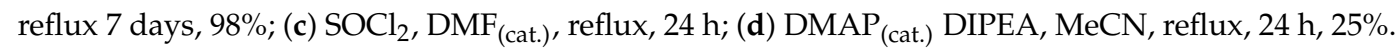

It is not clear from the current literature regarding the newly identified $D_{1} R$ PAM scaffold whether a single enantiomer or racemic mixture is responsible for the quoted in vitro activity. This led us to investigate methods to generate optically pure stereoisomers of compound 2. Numerous attempts at chiral resolution of $\mathbf{5}$ (semi-preparative chiral HPLC) and the chromatographic resolution of derivatives of $\mathbf{5}$ (diastereomeric amides/esters, diastereomeric salts) using various resolving ligands, e.g., (R)-1-phenylethan-1-amine, (S)-2-amino-2-phenylethan-1-ol, and (1R,2S,5R)-2-isopropyl-5-methylcyclohexan-1-ol ((-)menthol)), all failed. Therefore, to access enantiopure synthetic precursors, it was necessary to develop and explore the use of chiral auxiliaries in an ADA reaction. The Diels-Alder reaction arises from high regio- and stereoselectivity which also entails the use of various functionalised dienes and dienophiles, and much work has been done in the last three decades to develop ADA reactions, based on both enantiopure dienes and enantiopure dienophiles [39]. Accordingly, the area has been extensively reviewed [40-42].

(-)-Menthol 11, a chiral molecule with three stereocentres, was initially selected as a practical chiral auxiliary to probe the diastereoselectivity of the Diels-Alder cycloaddition. A derivative of 11, (-)-8-phenylmenthol, has previously been shown to induce ADA reactions with high distereoselectivity under $\mathrm{AlCl}_{3}$ catalysis [43]. As outlined in Scheme 2, DMAP-catalysed, EDC-mediated Steglich-type [44] esterification of methacrylic acid 12 with 11 furnished the corresponding auxiliary 13. This dienophile was subjected to a $\mathrm{TiCl}_{4}$-catalysed $[4+2]$ cycloaddition, affording cycloadduct(s) $14 .{ }^{1} \mathrm{H}$ NMR analysis 
confirmed that the $(1 R, 2 S, 5 R)$-menthol-acrylate chiral auxiliary conferred moderate diastereoselectivity in the cycloaddition as one diastereomer could be identified as the major product ( $>70 \%$ d.e.). Unfortunately, hydrolytic ester cleavage of 14 using $\mathrm{LiOH}$ or $\mathrm{NaOH}$ in refluxing THF $/ \mathrm{H}_{2} \mathrm{O}$ failed to furnish the acid (6) as no reaction was evident via LC/MS analysis. Alternative conditions for hydrolysis were sourced from work completed by Myers et al., who reported the use of various synthetic examples and reagents and to hydrolyse amides and esters [45]. Such additional methods were explored, including stirring 14 at reflux in the presence $\mathrm{H}_{2} \mathrm{SO}_{4}$ and 1,4-dioxane, stirring 14 reflux in 2:1:1 solution of $\mathrm{H}_{2} \mathrm{O}, \mathrm{MeOH}$ and tert-butanol in the presence of $\mathrm{NaOH}$, as well as at reflux in a 4:1 solution of $\mathrm{H}_{2} \mathrm{O} / 1$,4-dioxane in the presence of the Lewis acid iron(III) chloride hexahydrate. These chemistries all failed to provide the target acid.<smiles>CC1CCC(C(C)C)C(O)C1</smiles>

11

(b)<smiles></smiles>

4<smiles>C=C(C)C(=O)O</smiles>

12<smiles>CC(C)C1CC[C@@H](C)C[C@H]1OC(=O)[C@@]1(C)Cc2ccccc2-c2ccccc21</smiles>

$+$

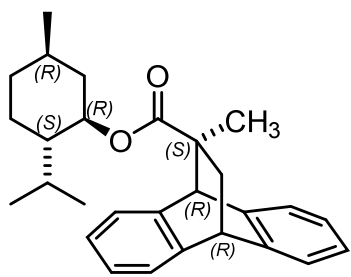

14 (a)<smiles>C=C(C)C(=O)O[C@H]1C[C@@H](C)CC[C@H]1C(C)C</smiles>

13

(ci)

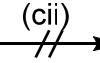

(ciii)

(civ)

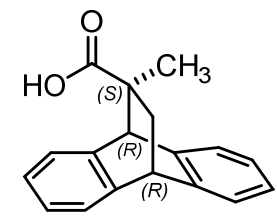

6

d.e. $>70 \%$

Scheme 2. Chemical synthesis of menthol-derived diastereomers using ADA chemistry. Reagents and conditions: (a) EDCI, DMAP (cat.), anhydrous $\mathrm{CH}_{2} \mathrm{Cl}_{2}$, r.t. $48 \mathrm{~h}, 55 \%$; (b) $\mathrm{TiCl}_{4}$, dry $\mathrm{CH}_{2} \mathrm{Cl}_{2}$, r.t. 15 h, 25\%; (ci) $\mathrm{NaOH}, \mathrm{THF} / \mathrm{H}_{2} \mathrm{O}$, reflux 7 d; (cii) $\mathrm{H}_{2} \mathrm{SO}_{4}$ (conc.), 1,4-dioxane, reflux, $3 \mathrm{~h}$; (ciii) $\mathrm{NaOH}$, 2:1:1 $\mathrm{H}_{2} \mathrm{O}, \mathrm{MeOH}$, $t$-butanol, reflux $72 \mathrm{~h}$; (civ) $\mathrm{FeCl}_{3} \cdot 6 \mathrm{H}_{2} \mathrm{O}, 1: 4$ 1,4-dioxane $/ \mathrm{H}_{2} \mathrm{O}$, reflux.

An additional auxiliary, (R)-2-amino-2-phenylethan-1-ol 15, was investigated for its potential in ADA chemistry. According to Scheme 3, methacrylic acid 12 was subjected to a potassium tert-butoxide mediated direct amidation [46] using 15, yielding the corresponding acrylamide 16. Again, the newly formed acrylamide was directly utilised in a $\mathrm{TiCl}_{4}$-cataysed [4+2]cycloaddition to furnish the desired ethanoanthracene derivative(s) 17 as a beige solid. HPLC analysis of the purified material indicated the presence of two diastereomers in an approximate diastereomic ratio (3:1) and this was further confirmed with ${ }^{1} \mathrm{H}$ NMR spectroscopy ( $37 \%$ d.e.). 

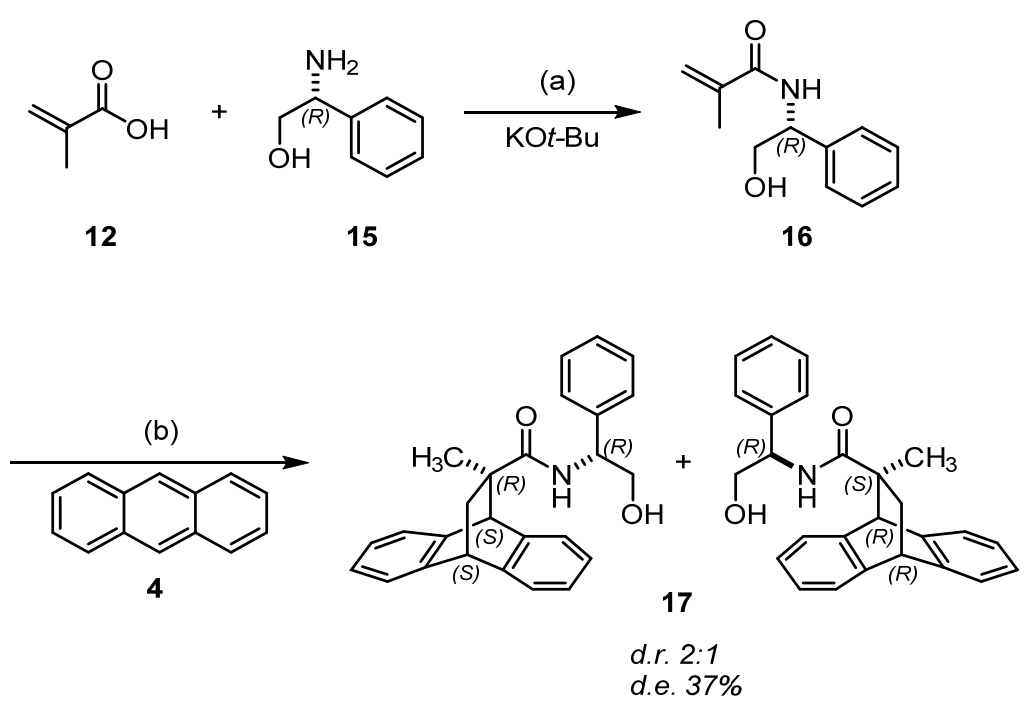

Scheme 3. Chemical synthesis of 2-phenylglycinol ethanoanthracene diastereomers. Reagents and conditions: (a) dry THF, r.t., 2.5 h, 91\%; (b) $\mathrm{TiCl}_{4}$, dry DCM, r.t. 7 days, $75 \%$.

The study of ADA induction involving esters derived from achiral acrylic and methacrylic acids, and the chiral auxiliaries $(R)$ - and (S)-3-hydroxy-4,4-dimethyl-1-phenyl-2-pyrrolidinone with different dienes including anthracene (which was of particular interest), catalysed by $\mathrm{TiCl}_{4}$ has been described [39]. These studies reported adducts derived from anthracene and the (R)-pantolactam-acrylate ester could be obtained with high facial-diasteroselectivity where subsequent ester saponification afforded the corresponding enantiopure acid in high optical purity. In addition, the acrylates of $(R)$-pantolactone have also been extensively studied for their asymmetric capacity to direct cycloadditions with high facialdiastereoselectivity for a number of diene scaffolds under $\mathrm{TiCl}_{4}$ catalysis, including anthracene [47-49]. Pantolactones and their use as chiral auxiliaries in ADA chemistry has been extensively reviewed [50], as well as mechanistic models proposed to explain the sense of asymmetric induction in $\mathrm{TiCl}_{4}$-catalysed $\mathrm{ADA}$ reactions of pantolactone-acrylate derivatives [51].

Following an adapted procedure from Camps et al. [39], and as outlined in Scheme 4, commercially available D-pantolactone $((R)-\mathbf{1 8})$ was reacted with methacrylic acid $\mathbf{1 2}$ under modified Steglich esterification [44] conditions to give the corresponding auxiliary $(R)-19$ in moderate yield. Subsequent [ $4+2]$ cycloaddition with anthracene 4 as the diene in the presence of $\mathrm{TiCl}_{4}$ as catalyst, followed by chromatographic purification and recrystallization from EtOH, afforded (S)-20 as a pale white crystalline solid. ${ }^{1} \mathrm{H}$ NMR spectroscopic analysis confirmed high diasteroselectivity ( $>90 \%$ d.e.) for the asymmetric induction. Basic ester saponification using a large excess of $\mathrm{NaOH}$ in refluxing $\mathrm{THF} / \mathrm{H}_{2} \mathrm{O}$ was achieved to eventually yield carboxylic acid (S)-21. Although the synthesis of ((S)-21) has been reported in the literature using (R)-3-hydroxy-4,4-dimethyl-1-phenyl-2-pyrrolidinone as a chiral auxiliary [39] our synthesis was performed to examine the asymmetric induction potential of pantolactone chiral auxiliaries. Moreover, $((S)$-21) was subsequently required to form the corresponding amide (S)-2, so as it could be evaluated for its in vitro allosteric ligand parameters. The enantiopurity of $(S)-21$ was characterised using polarimetry $[\alpha]_{\mathrm{D}}^{25}=-24.9^{\circ}$ $\left(c 1.0, \mathrm{CHCl}_{3}\right)$ which was in accordance with literature values [39]. Based on approximations from the preceding ${ }^{1} \mathrm{H}$ NMR spectrum of (S)-20, an enantiomeric excess (e.e.) of $>90 \%$ was likely. Indeed, chiral HPLC (cHPLC) confirmed the presence of predominantly a single enantiomer, supporting the high facial-diastereoselectivity of the pantolactone chiral auxiliary in [ $4+2]$ cycloadditions, with e.e. calculated to be $\sim 88 \%$. The enantioenriched mixture was successively activated with thionyl chloride and subjected to nucleophilic substitution employing conditions outlined previously, yielding enantioenriched (S)-2. CHPLC analysis of (S)-2 determined the e.e. to be $\sim 90 \%$. 


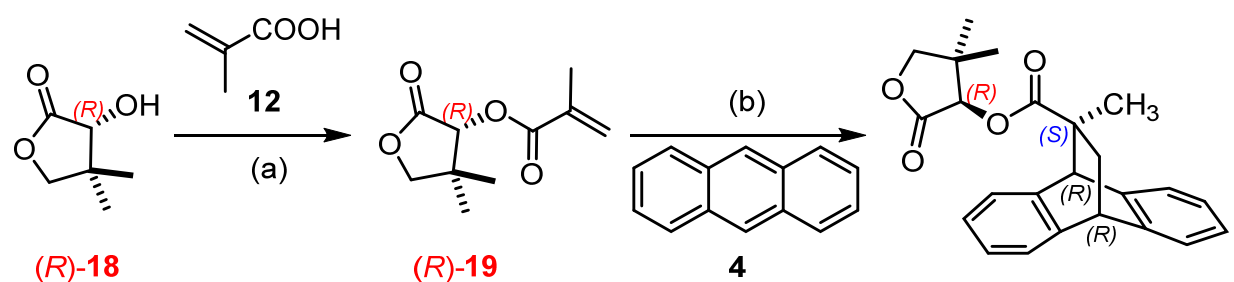

[or (S)-18] [or (S)-19]

(S)-20 (d.e. 90\%)

(R)-20 (d.e. 83\%)

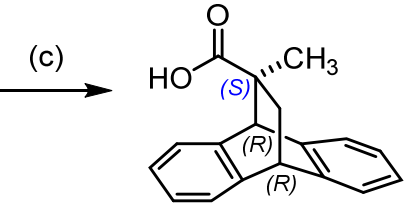

(S)-21 (e.e. 88\%) [or (R)-21] (e.e. 83\%)
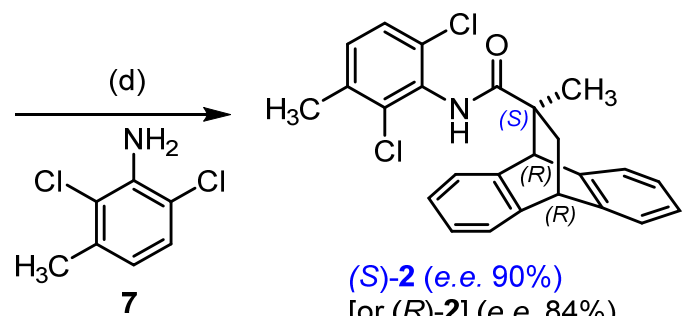

(S)-2 (e.e. 90\%) [or (R)-2] (e.e. 84\%)

Scheme 4. Enantioenrichment of optical isomers of 2 using chiral auxiliaries derived from pantolactone. Reagents and conditions: (a) EDCI, DMAP, dry $\mathrm{CH}_{2} \mathrm{Cl}_{2}$, r.t. 10 h, 69-87\% ((R)-19, (S)-19); (b) $\mathrm{TiCl}_{4}$, dry $\mathrm{CH}_{2} \mathrm{Cl}_{2}$, r.t. 15 h, 80-85\% ((S)-20, (R)-20); (c) $\mathrm{NaOH}, \mathrm{THF} / \mathrm{H}_{2} \mathrm{O}$, reflux, $72 \mathrm{~h}, 85-98 \%$ ((S)-21, (R)-21); (d) $\mathrm{SOCl}_{2}$ (neat), $\mathrm{DMF}_{\text {(cat.) }}$ reflux, $24 \mathrm{~h}$, then acyl halide, $\operatorname{DMAP}_{\text {(cat.) }}$ DIPEA, MeCN, reflux, 24 h, 19-25\% ((S)-2, (R)-2).

Interestingly, Camps et al. reported that a racemic $N$-phenyl pantolactam chiral auxiliary was unable to react with anthracene under $\mathrm{AlCl}_{3}$ catalysis [39]. In addition, the authors did not report on the effectiveness of $\mathrm{TiCl}_{4}$ as catalyst for the cycloaddition reaction between anthracene and their $(S)-N$-phenyl pantolactam chiral auxiliary, nor its racemic counterpart. Thus, the asymmetric induction potential of using the structurally related (S)-pantolactone acrylate ester ((S)-19) as an alternative chiral auxiliary to access the previously unreported $(R)-20$ was unknown. This chemistry is illustrated in Scheme 4 commencing with Steglich esterification [44] of $\mathbf{1 2}$ with commercially available L-pantolactone (S)-18) using conditions outlined previously to afford (S)-19. Subsequent cycloaddition of the auxiliary (S)-19 with diene 4 gave cycloadduct $(R)-20$ in good yield, with ${ }^{1} \mathrm{H}$ NMR indicating a slightly lower diastereoselectivity (d.e. $\sim 83 \%$ ). This apparent reduced asymmetry may have arisen from a failure for $(R)-20$ to recrystallize, or is mechanistically inherent in the cycloaddition of (S)-19. Hydrolytic cleavage of the auxiliary was achieved using forcing alkaline conditions, eventually affording the free carboxylic acid $(R)-21$. An assessment of the enantiopurity was again made using polarimetry $\left([\alpha]_{\mathrm{D}}^{25}=+24.1^{\circ}\left(c 1.0, \mathrm{CHCl}_{3}\right)\right)$, whereby subsequent chiral HPLC analysis determined the e.e. to be $\sim 82 \%$. Acyl halide formation and nucleophilic displacement with 7 using conditions outlined previously furnished the corresponding enantioenriched $(R)$-2. CHPLC analysis of $(R)-2$ determined the e.e. to be $\sim 84 \%$.

\subsection{Pharmacology}

Previous work by Lewis et al. [36] reported rac-2 as a PAM at the $\mathrm{D}_{1} \mathrm{R}$ with superior potency $\left(\mathrm{EC}_{50}=43 \mathrm{nM}\right)$ and no agonist activity. We tested rac-2 in an assay measuring accumulation of cyclic adenosine monophosphate (cAMP) through activation of the $h D_{1} R$ stably expressed in FlpIn CHO cells using a BRET biosensor [52]. Concentration-response curves of DA were generated in the presence of increasing concentrations of test compound. An operational model of allostery was applied to these data, allowing us to determine estimates of functional affinity for the unoccupied receptor $\left(K_{B}\right)$, a composite measure of allosteric cooperativity $(\alpha \beta)$ that combines cooperativity with DA affinity $(\alpha)$ and modulatory effect upon DA efficacy $(\beta)$, as well as the intrinsic efficacy $\left(\tau_{B}\right)$ of the allosteric ligand. Values of $\alpha \beta>1$ indicate a positive modulatory effect. Functional assessment of rac-2 in our hands showed it exhibited modest affinity for the $\mathrm{D}_{1} \mathrm{R}\left(K_{B}=1.6 \mu \mathrm{M}\right.$, Figure $2 \mathrm{~A}$, Table 1), acting to potentiate the potency of DA 100 -fold $(\alpha \beta=100)$ as well as display 
allosteric agonism $\left(\tau_{B}=2.1\right.$, Table 1$)$. Lewis and colleagues observed that rac-2 did not display agonism. This difference likely reflects a difference in the cell background ( $\mathrm{CHO}$ versus HEK293) and/or a higher level of $\mathrm{D}_{1} \mathrm{R}$ expression in our cell line and/or a greater sensitivity of our cAMP assay [36]. Indeed, such effects have been observed for a PAM of the muscarinic $\mathrm{M}_{1}$ acetylcholine receptor and such observations are consistent with a two-state model of allostery [53]. Consistent with the above differences, the potency of DA in our assay is also greater than that observed by Lewis and coworkers in their experiments. Note that Lewis et al. also determined the value of potency for rac-2 as $40 \mathrm{nM}$. This value was determined by the measuring the potency with which rac-2 causes a shift in DA potency and cannot be directly compared with the value of $K_{B}$ determined in our analysis that reflects the affinity of the PAM for the unoccupied receptor.

A

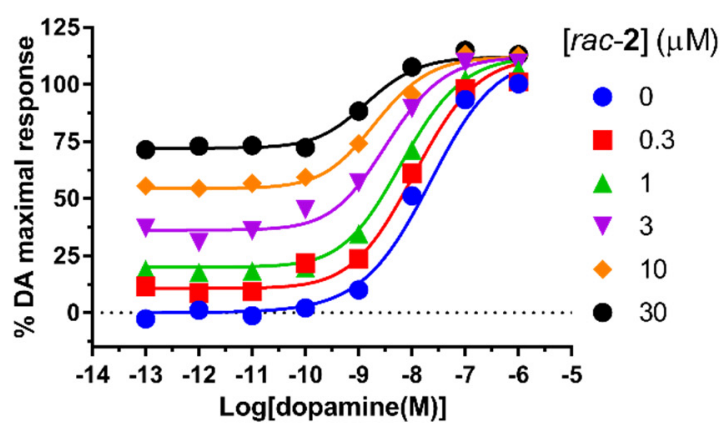

C

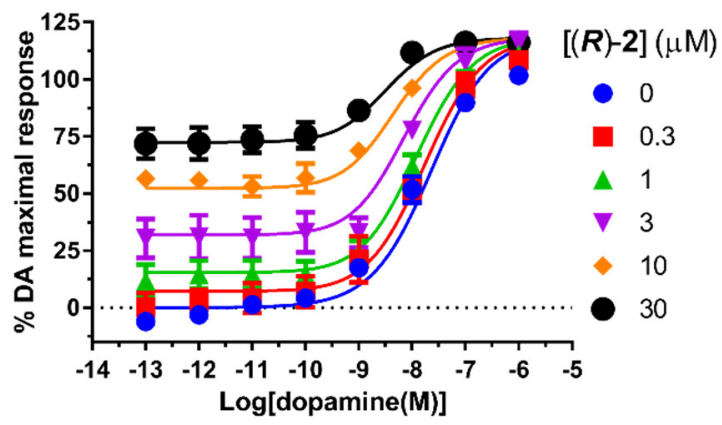

B

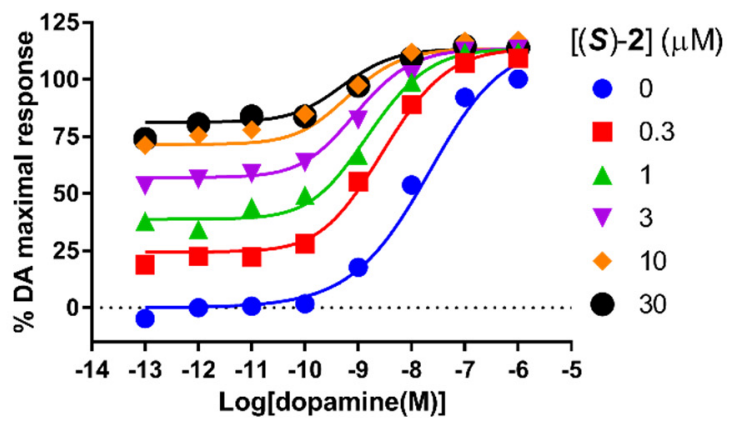

D

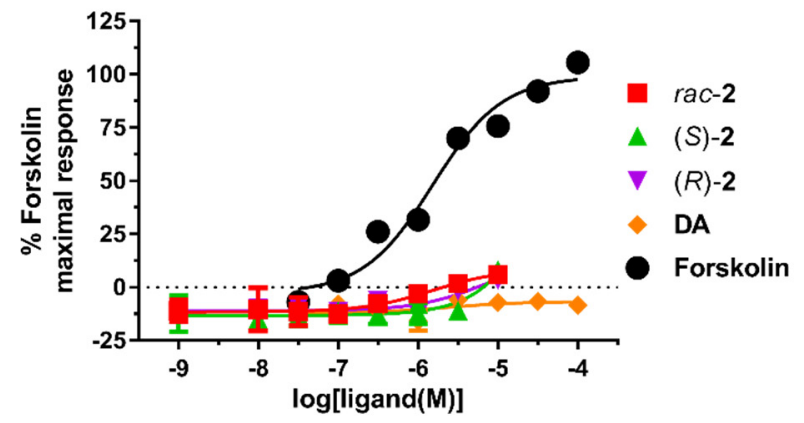

Figure 2. All compounds display allosteric pharmacology at the $\mathrm{D}_{1} \mathrm{R}$ in an assay measuring cAMP production using a BRET biosensor. rac-2 (A), the enantioenriched $S$-isomer (S)-2, (B), and the enantioenriched $R$-isomer $(R)-2,(C)$ act as an ago-PAMs, potentiating DA potency and exerting allosteric agonism. These data were fitted to an operational model of agonism to derive values of affinity, cooperativity with DA and intrinsic efficacy (see Table 1). Data are presented as mean \pm S.D. from

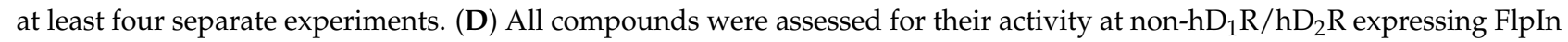
$\mathrm{CHO}$-cells transfected with the BRET biosensor, demonstrating that compound activity is mediated through the $\mathrm{D}_{1} / \mathrm{D}_{2} \mathrm{Rs}$. Data are presented as mean \pm S.D. from at least four separate experiments.

Intriguingly, the optical isomers of rac-2 ((S)-2, (R)-2) were shown to display significant differences both in their affinity for the $D_{1} R$ and their degree of positive allosteric cooperativity with DA. The enantioenriched $(S)-2$ was determined to have comparable functional affinity, efficacy and cooperativity as compared to rac-2 $\left(K_{B}=1 \mu \mathrm{M}, \alpha \beta=125\right.$, $\tau_{B}=2.5$ ) (Figure $2 B$, Table 1). Conversely, the enantioenriched $(R)-2$ displayed 4.8 -fold and 7.4-fold lower functional affinity $\left(K_{B}=7.4 \mu \mathrm{M} \alpha \beta=31\right)$ and 3-fold and 4-fold lower cooperativity with DA, relative to rac-2 and (S)-2 respectively (Figure $2 \mathrm{C}$, Table 1 ). It is interesting to note that the pharmacology of $r a c-2$ is not significantly different from $(S)$ 2. This can be reconciled by the lower levels of affinity and cooperativity with DA that (R)-2 displays. These two factors combined mean that (S)-2 would effectively display a 30 -fold greater affinity for the DA occupied receptor as compared to $(R)-2$ even though 
their affinities for the unoccupied are a more modest 7 -fold different. In the racemate, therefore, (S)-2 would be expected to dominate meaning that the pharmacology of the racemate reflects this enantiomer. We extended our functional characterisation of these compounds to an assay measuring inhibition of forskolin-stimulated cAMP accumulation in $\mathrm{hD}_{2 \mathrm{~L}} \mathrm{R}$-expressing FlpIN CHO cells. rac-2 and its respective enantiomers $((R)-2,(S)-2)$ displayed no activity at the $D_{2} R$ up to a measured concentration of $30 \mu \mathrm{M}$. None of the above compounds displayed any off-target response in FlpIn CHO cells transfected with the BRET biosensor, but not expressing either the $D_{1} R$ or the $D_{2} R$ (Figure 2D). Together our data indicate that the distinct structural configuration of the two enantiomers of $\mathbf{2}$ confer differences in their ability to potentiate DA at the $\mathrm{D}_{1} \mathrm{R}$.

Table 1. Functional parameters for PAMs derived from cAMP BRET assay at the $\mathrm{hD}_{1} \mathrm{R}$.

\begin{tabular}{ccccc}
\hline CPD & e.e. $(\%)$ & $\mathrm{pK}_{B}\left(\boldsymbol{K}_{\boldsymbol{B}}, \boldsymbol{\mu M}\right)^{1}$ & $\log \tau_{B}\left(\tau_{B}\right)^{2}$ & $\log \alpha \beta(\alpha \beta)^{3}$ \\
\hline$r a c-2$ & 0 & $5.80 \pm 0.10(1.6)$ & $0.32 \pm 0.06(2.1)$ & $2.00 \pm 0.12(100)$ \\
$(S)-2$ & 90 & $5.99 \pm 0.09(1.0)$ & $0.40 \pm 0.06(2.5)$ & $2.10 \pm 0.25(125)$ \\
$(R)-2$ & 84 & $5.12 \pm 0.06(7.6)^{*, \wedge}$ & $0.46 \pm 0.08(2.9)$ & $1.51 \pm 0.14(31)^{*, \wedge}$ \\
\hline
\end{tabular}

${ }^{1}$ Estimate of the negative logarithm of the equilibrium dissociation constant determined in an cAMP functional assay. ${ }^{2}$ Estimate of the intrinsic efficacy of the modulator. ${ }^{3}$ Estimate of the logarithm of the net cooperativity factor between the modulator and DA. Values represent mean \pm S.D. from at least four independent experiments performed in duplicate. Significant differences parameter between $(R)-2$ and $r a c-2{ }^{*}$ or $(S)-2^{\wedge}, p<0.05$, one-way ANOVA with Tukey's Post-hoc test (GraphPad Prism Version 7).

\section{Experimental}

\subsection{General}

Solvents and fine chemicals were commercially available from standard suppliers and used where described without further purification. Davisil silica gel $(40-63 \mu \mathrm{m})$ for Flash column chromatography used Davisil silica gel (40-63 $\mu \mathrm{m})$ and was supplied by Grace Davison Discovery Sciences (Victoria, Australia). Deuterated solvents for NMR spectroscopy were sourced by Novachem Pty. Ltd., Victoria, Australia (a distributor for Cambridge Isotope Laboratories, Inc., Tewksbury, MA, USA). Reactions were monitored by thin layer chromatography on commercially available precoated aluminum-backed plates (Merck Kieselgel $\left.60 \mathrm{~F}_{254}\right)$. Visualization was by inspection under UV light $(254 \mathrm{~nm} / 366 \mathrm{~nm}$ ). Ninhydrin (in EtOH) was used to visualize primary and secondary amines. Anhydrous $\mathrm{Na}_{2} \mathrm{SO}_{4}$ was used to dry all organic extracts collected after aqueous workup procedures before gravity/vacuum filtration and evaporation to dryness. Organic solvents were removed under reduced pressure at a water bath temperature of $\leq 40{ }^{\circ} \mathrm{C} .{ }^{1} \mathrm{H}$ NMR and ${ }^{13} \mathrm{C}$ NMR spectra were recorded on a Bruker Avance Nanobay III $400 \mathrm{MHz}$ Ultrashield Plus spectrometer at 400.13 and $100.62 \mathrm{MHz}$, respectively. Chemical shifts $(\delta)$ are recorded in parts per million (ppm) with reference to the chemical shift of the deuterated solvent. Coupling constants $(J)$ are recorded in $\mathrm{Hz}$, and multiplicities described by singlet (s), doublet $(\mathrm{d})$, triplet $(\mathrm{t})$, quadruplet $(\mathrm{q})$, broad $(\mathrm{br})$, multiplet $(\mathrm{m})$, doublet of doublets (dd), and doublet of triplets (dt). All NMR experiments were performed in $\mathrm{CDCl}_{3}$ for comparison of spectra of various analogues. For analogues that displayed reduced solubility in $\mathrm{CDCl}_{3}$ then experiments were performed in $\mathrm{CD}_{3} \mathrm{OD}$, DMSO- $d_{6}$, or acetone- $d_{6}$. LCMS experiments -System A (default): an Agilent 6100 series single quad coupled to an Agilent 1200 series HPLC instrument using the following buffers: buffer $\mathrm{A}, 0.1 \% \mathrm{HCOOH}$ in $\mathrm{H}_{2} \mathrm{O}$; buffer $\mathrm{B}$, $0.1 \% \mathrm{HCOOH}$ in $\mathrm{CH}_{3} \mathrm{CN}$. The following gradient was used with a Phenomenex Luna $3 \mu \mathrm{m}$ C8(2) $15 \times 4.6 \mathrm{~mm}$ column, flow rate of $0.5 \mathrm{~mL} / \mathrm{min}$, total run time of $12 \mathrm{~min}: 0-4 \mathrm{~min}$ $95 \%$ buffer $\mathrm{A} / 5 \%$ buffer B, $4-7$ min $0 \%$ buffer $\mathrm{A} / 100 \%$ buffer $\mathrm{B}, 7-12$ min $95 \%$ buffer A $/ 5 \%$ buffer $B$. Mass spectra were acquired in both negative \& positive ion modes with a scan range of $0-1000 \mathrm{~m} / z$ at $5 \mathrm{~V}$. UV detection was monitored at $254 \mathrm{~nm}$. System B: an Agilent 6120 series single quad coupled to an Agilent 1260 series HPLC instrument using the following buffers; buffer $\mathrm{A}, 0.1 \% \mathrm{HCOOH}$ in $\mathrm{H}_{2} \mathrm{O}$; buffer $\mathrm{B}, 0.1 \% \mathrm{HCOOH}$ in $\mathrm{CH}_{3} \mathrm{CN}$. The following gradient was used with a Poroshell 120 EC-C18 $50 \times 3.0 \mathrm{~mm}$, $2.7 \mu \mathrm{m}$ column, flow rate of $0.5 \mathrm{~mL} / \mathrm{min}$, total run time of $5 \mathrm{~min}$ : $0-1 \mathrm{~min} 95 \%$ buffer 
A/5\% buffer B, 1 to 2.5 min $0 \%$ buffer $A / 100 \%$ buffer B, held until 3.8 min, 3.8-4 min $95 \%$ buffer $\mathrm{A} / 5 \%$ buffer $\mathrm{B}$, held until $5 \mathrm{~min}$. Mass spectra were acquired in both negative \& positive ion modes with a scan range of $100-1000 \mathrm{~m} / z$. UV detection was monitored at 214 and $254 \mathrm{~nm}$. All retention times $\left(t_{R}\right)$ were quoted in minutes. System C: analytical reverse-phase HPLC was performed, to verify purity, on a Waters HPLC system coupled directly to a photodiode array detector and fitted with a Phenomenex Luna C8 (2) $100 \AA$ column $(150 \times 4.6 \mathrm{~mm}, 5 \mu \mathrm{m})$. A binary solvent system of buffer $\mathrm{A}, 0.1 \% \mathrm{TFA} / \mathrm{H}_{2} \mathrm{O}$; buffer $\mathrm{B}, 0.1 \% \mathrm{TFA} / 80 \% \mathrm{CH}_{3} \mathrm{CN} / \mathrm{H}_{2} \mathrm{O}$ was used. Gradient elution was attained using $100 \%$ buffer A to $100 \%$ buffer B over $12 \mathrm{~min}$ at a flow rate of $1 \mathrm{~mL} / \mathrm{min}$. All target compounds subjected to biological testing were $>95 \%$ pure by HPLC at two wavelengths (214 and $254 \mathrm{~nm}$ ). Analytical chiral-HPLC were conducted on an Agilent Infinity 1260 system fitted with either one of (a) Lux $5 \mu \mathrm{m}$ Amylose-2 $150 \times 4.60 \mathrm{~mm}$, or (b) Lux $5 \mu \mathrm{m}$ Cellulose-1 $150 \times 4.60 \mathrm{~mm}$. A binary solvent system was used (solvent A: ethanol; solvent B: petroleum spirits), with UV detection at $254 \mathrm{~nm}$. The method used isocratic elution of 1-20\% solvent $\mathrm{A}$ and $99-80 \%$ solvent $\mathrm{B}$, with a flow rate of $1 \mathrm{~mL} / \mathrm{min}$. Mass spectra were acquired in in both negative \& positive ion mode with a scan range of 100-1000 $\mathrm{m} / \mathrm{z}$. UV detection was monitored at 214 and $254 \mathrm{~nm}$ with retention times $\left(t_{R}\right)$ expressed in minutes. All screening compounds displayed $>95 \%$ purity unless otherwise specified in the individual monologue.

\subsection{Chemistry}

\subsubsection{General Procedure A for Steglich Esterification}

A mixture of methacrylic acid (1.0 equiv.) alcohol (1.0 equiv.), EDC (1.1 equiv.) and DMAP (5 mol \%) in dry DCM was stirred at rt until complete consumption of the starting acid or alcohol. The reaction mixture was washed with sat. aqueous citric acid $(3 \times 50 \mathrm{~mL})$ and sat. aqueous $\mathrm{NaHCO}_{3}(3 \times 50 \mathrm{~mL})$, dried $\left(\mathrm{Na}_{2} \mathrm{SO}_{4}\right)$ and concentrated in vacuo. The residue was purified by flash column chromatography (FCC) with an appropriate eluent as indicated.

\subsubsection{General Procedure B for $\mathrm{TiCl}_{4}$-Catalysed Diels-Alder Cycloaddition}

A solution of $\mathrm{TiCl}_{4}$ (2.0 equiv.) in anhydrous DCM $(20 \mathrm{~mL})$ was added to a solution of the appropriate chiral auxiliary/dienophile (1.0 equiv.) in anhydrous DCM $(30 \mathrm{~mL})$, and the mixture stirred at $\mathrm{rt}$ for $15 \mathrm{~min}$. Then, a solution of the anthracene (1.0 equiv.) in dry $\mathrm{CH}_{2} \mathrm{Cl}_{2}(20 \mathrm{~mL})$ was added and the mixture stirred at r.t. for $15 \mathrm{~h}$. A small amount of $\mathrm{H}_{2} \mathrm{O}$ was added to destroy the $\mathrm{TiCl}_{4}$ complexes, the mixture was filtered and the filtrate was dried with anhydrous $\mathrm{Na}_{2} \mathrm{SO}_{4}$. The filtrate was concentrated in vacuo and the residue was purified by FCC using an appropriate eluent as indicated.

\subsubsection{General Procedure $C$ for Alkaline Ester Hydrolysis}

To a solution of ester (1.0 equiv.) in a 1:1 mixture of THF $/ \mathrm{H}_{2} \mathrm{O}$ was added $\mathrm{NaOH}$ (3 equiv.), and the mixture stirred at reflux temperature until complete consumption of the starting material was evident. The THF was removed in vacuo and the remaining aqueous phase was washed with $\mathrm{Et}_{2} \mathrm{O}$. The aqueous phase was then acidified $(\mathrm{pH}=1)$, and any precipitated carboxylic acid was collected via vacuum filtration and recrystallised from EtOAc/PE. Similarly, the aqueous phase could be extracted with DCM and the organic extracts dried $\left(\mathrm{Na}_{2} \mathrm{SO}_{4}\right)$ to afford the desired carboxylic acid to maximise the yield.

\subsubsection{General Procedure D for Acyl Halide Formation and Nucleophilic Substitution}

The carboxylic acid (1 equiv.) was taken up in thionyl chloride $(5 \mathrm{~mL})$ followed by three drops of DMF and the reaction was stirred at reflux temperature until complete consumption of the starting material. The solvent was removed in vacuo and the residue was taken up in dry $\mathrm{MeCN}(25 \mathrm{~mL})$. To this solution was added 2,6-dichloro-3-methylaniline (1.1 equiv.), DMAP (0.5 equiv.), DIPEA (2.0 equiv.), and stirred at reflux temperature until complete consumption of the acyl halide was evident. The solvent was evaporated under 
reduced pressure and the residue was taken up in EtOAc, washed with $1 \mathrm{M}$ aqueous $\mathrm{NaOH}, \mathrm{H}_{2} \mathrm{O}, 1 \mathrm{M}$ aqueous $\mathrm{HCl}$, brine, and the organic layer dried $\left(\mathrm{Na}_{2} \mathrm{SO}_{4}\right)$. The solvent was concentrated in vacuo and the residue purified by FCC with an appropriate eluent as indicated.

Methyl (rel-9S,10S,12R)-12-methyl-9,10-dihydro-9,10-ethanoanthracene-12-carboxylate [38] (5)

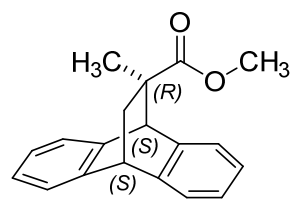

Methyl methacrylate ( $3.29 \mathrm{~mL}, 30.9 \mathrm{mmol}, 1.1$ eq.) was added to a suspension of $\mathrm{AlCl}_{3}$ $(3.74 \mathrm{~g}, 28.1 \mathrm{mmol}, 1.0$ eq.) in dry DCM $(100 \mathrm{~mL})$, in a three-necked round-bottom flask under a positive pressure of $\mathrm{N}_{2}$. After $1 \mathrm{~h}$ of stirring, anthracene $(5.00 \mathrm{~g}, 28.1 \mathrm{mmol}, 1.0 \mathrm{eq}$.) was added portion-wise. The resulting mixture was stirred at room temperature for $72 \mathrm{~h}$ or until complete consumption of the anthracene was evident. The mixture was then poured over ice, the organic layer separated, washed with water $(40 \mathrm{~mL})$, dried $\left(\mathrm{Na}_{2} \mathrm{SO}_{4}\right)$, and the solvent evaporated. The resulting residue was dissolved in DCM, absorbed onto silica gel and purified by FCC (eluent, 9:1 PE/ $\mathrm{Et}_{2} \mathrm{O}$ ) to afford the title compound as a transparent oil which solidified under high vacuum to give a white solid (5.67 g, 72\%). LCMS $(m / z): 301.1$ $[\mathrm{M}+\mathrm{Na}]^{+}$. System C HPLC: $t_{\mathrm{R}} 8.389 \mathrm{~min},>95 \%$ purity $(214 \& 254 \mathrm{~nm}) .{ }^{1} \mathrm{H} \mathrm{NMR}\left(\mathrm{CDCl}_{3}\right)$ 8 7.32-7.28 (m, 1H), 7.26-7.22 (m, 2H), $7.19(\mathrm{dd}, J=6.9,1.6 \mathrm{~Hz}, 1 \mathrm{H}), 7.13-7.08(\mathrm{~m}, 2 \mathrm{H})$, $7.08-7.01(\mathrm{~m}, 2 \mathrm{H}), 4.40(\mathrm{~s}, 1 \mathrm{H}), 4.25(\mathrm{t}, J=2.7 \mathrm{~Hz}, 1 \mathrm{H}), 3.53(\mathrm{~s}, 3 \mathrm{H}) 2.71(\mathrm{dd}, J=12.7,3.0 \mathrm{~Hz}$, $1 \mathrm{H}), 1.39(\mathrm{dd}, J=12.7,2.5 \mathrm{~Hz}, 1 \mathrm{H}), 1.05(\mathrm{~s}, 3 \mathrm{H}) .{ }^{13} \mathrm{C} \mathrm{NMR}\left(\mathrm{CDCl}_{3}\right) \delta 177.2,143.8,143.2$, 141.6, 140.5, 126.4, 126.2, 126.2, 125.7, 125.6, 124.7, 123.6, 123.2, 52.9, 52.1, 44.5, 38.9, 26.7. rel-(9S,10S,12R)-12-Methyl-9,10-dihydro-9,10-ethanoanthracene-12-carboxylic acid (6)

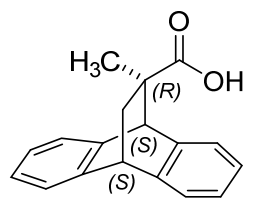

Synthesised according to general procedure C using $\mathrm{LiOH}_{\mathrm{H}} \mathrm{H}_{2} \mathrm{O}(2.15 \mathrm{~g}, 89.8 \mathrm{mmol})$. After acidification, the precipitated solids were washed with water and recrystallised from EtOAc/PE, affording the compound as white needles (4.75 g, quantitative). LCMS $(m / z)$ : $263.1[\mathrm{M}-\mathrm{H}]^{+}$. System C HPLC: $t_{\mathrm{R}} 7.181 \mathrm{~min},>95 \%$ purity $(214 \& 254 \mathrm{~nm}) .{ }^{1} \mathrm{H}$ NMR $\left(\mathrm{CDCl}_{3}\right)$ \& 7.31-7.28 (m, 1H), 7.27-7.23 (m, 3H), 7.23-7.19 (m, 1H), 7.12 (ddd, $J=6.1$, 5.6, $3.7 \mathrm{~Hz}, 2 \mathrm{H}), 7.08(\mathrm{dd}, J=7.2,1.5 \mathrm{~Hz}, 1 \mathrm{H}), 7.06-7.01(\mathrm{~m}, 1 \mathrm{H}), 4.37(\mathrm{~s}, 1 \mathrm{H}), 4.26(\mathrm{t}, J=2.7 \mathrm{~Hz}$, $1 \mathrm{H}), 2.62(\mathrm{dd}, J=12.7,3.0 \mathrm{~Hz}, 1 \mathrm{H}), 1.40(\mathrm{dd}, J=12.7,2.5 \mathrm{~Hz}, 1 \mathrm{H}), 1.07(\mathrm{~s}, 3 \mathrm{H}) .{ }^{13} \mathrm{C} \mathrm{NMR}$ $\left(\mathrm{CDCl}_{3}\right) \delta 181.7,143.6,143.3,141.3,140.5,126.5,126.3,126.2,125.8,125.7,125.2,123.5,123.3$, $52.6,48.5,44.5,38.7,26.9$. Analytical data including ${ }^{1} \mathrm{H}$ NMR and ${ }^{13} \mathrm{C}$ NMR spectra are in accordance with those published [26,39].

rel-(9R,10R,12S)-N-(2,6-Dichloro-3-methylphenyl)-12-methyl-9,10-dihydro-9,10-ethanoanth racene-12-carboxamide (rac-2)<smiles>Cc1ccc(Cl)c(NC(=O)C2c3ccccc3-c3ccccc32)c1Cl</smiles>

Synthesised according to general procedure D using oxalyl chloride $(243 \mu \mathrm{L}, 2.84 \mathrm{mmol})$, rel$(9 S, 10 S, 12 R)-12$-methyl-9,10-dihydro-9,10-ethanoanthracene-12-carboxylic acid (6) (375 mg, 
$1.42 \mathrm{mmol}), \mathrm{DMAP}(4.32 \mathrm{mg}, 35.4 \mathrm{mmol})$, DIPEA $(120 \mu \mathrm{L}, 707 \mu \mathrm{mol})$ and 2,6-dichloro-3methylaniline $(65.4 \mathrm{mg}, 371 \mu \mathrm{mol})$. Purification by FCC (eluent, 10:1 PE/EtOAc) afforded the racemic compound as a white solid $(75 \mathrm{mg}, 50 \%)$. LCMS $(m / z): 446.1[\mathrm{M}+\mathrm{Na}]^{+}$, $423.1[\mathrm{M}+\mathrm{H}]^{+}$. System C HPLC: $t_{\mathrm{R}} 8.496 \mathrm{~min},>95 \%$ purity $(214 \& 254 \mathrm{~nm})$. HRMS $(\mathrm{m} / z)$ : $\mathrm{C}_{25} \mathrm{H}_{21} \mathrm{C}_{12} \mathrm{NO}$ : requires $422.1083[\mathrm{M}+\mathrm{H}]^{+}$; found 422.1073. ${ }^{1} \mathrm{H} \mathrm{NMR}\left(\mathrm{CDCl}_{3}\right) \delta 7.40-7.37$ $(\mathrm{m}, 1 \mathrm{H}), 7.34-7.31(\mathrm{~m}, 1 \mathrm{H}), 7.30-7.25(\mathrm{~m}, 2 \mathrm{H}), 7.18-7.11(\mathrm{~m}, 3 \mathrm{H}), 7.08-7.01(\mathrm{~m}, 3 \mathrm{H}), 6.89$ (s, $1 \mathrm{H}), 4.52(\mathrm{~s}, 1 \mathrm{H}), 4.34(\mathrm{t}, J=2.6 \mathrm{~Hz}, 1 \mathrm{H}), 2.64(\mathrm{dd}, J=12.5,2.8 \mathrm{~Hz}, 1 \mathrm{H}), 2.29(\mathrm{~s}, 3 \mathrm{H}), 1.66$ $(\mathrm{dd}, J=12.4,2.7 \mathrm{~Hz}, 1 \mathrm{H}), 1.18(\mathrm{~s}, 3 \mathrm{H}) .{ }^{13} \mathrm{C} \mathrm{NMR}\left(\mathrm{CDCl}_{3}\right) \delta 174.7,143.3,143.2,141.5,141.4$, $136.1,133.8,132.2,130.8,129.6,127.4,126.5,126.4,126.2,125.9,125.9,125.7,123.5,123.2$, $52.7,49.2,44.7,40.3,28.3,20.5$. Analytical data including ${ }^{1} \mathrm{H}$ NMR and ${ }^{13} \mathrm{C}$ NMR spectra are in accordance with those published [26]. $(1 R, 2 S, 5 R)-2-I s o p r o p y l-5-m e t h y l c y c l o h e x y l$ methacrylate (13)<smiles>C=C(C)C(=O)O[C@H]1C[C@@H](C)CC[C@H]1C(C)C</smiles>

Synthesised according to general procedure A using methacrylic acid (1.62 mL, 19.2 $\mathrm{mmol}),(1 R, 2 S, 5 R)-2$-isopropyl-5-methylcyclohexan-1-ol (3.00 g, $19.2 \mathrm{mmol})$, EDC (4.05 g, $21.2 \mathrm{mmol}$ ) and DMAP (117 mg, $960 \mu \mathrm{mol})$. Purification by FCC (eluent, DCM) gave the title compound as a transparent oil (3.20 g, 74\%). LCMS $(m / z): 225.2[\mathrm{M}+\mathrm{H}]^{+}$. System C HPLC: $t_{\mathrm{R}} 9.042 \mathrm{~min},>95 \%$ purity $(214 \& 254 \mathrm{~nm}) .{ }^{1} \mathrm{H} \mathrm{NMR}\left(\mathrm{CDCl}_{3}\right) \delta 6.23-6.20(\mathrm{~m}, 1 \mathrm{H})$, $5.81(\mathrm{dd}, J=2.0,1.2 \mathrm{~Hz}, 1 \mathrm{H}), 3.39(\mathrm{td}, J=10.4,4.3 \mathrm{~Hz}, 1 \mathrm{H}), 2.16(\mathrm{dtd}, J=14.0,7.0,2.7 \mathrm{~Hz}$, $1 \mathrm{H}), 1.99(\mathrm{dt}, J=1.5,0.9 \mathrm{~Hz}, 3 \mathrm{H}), 1.95-1.91(\mathrm{~m}, 1 \mathrm{H}), 1.61(\mathrm{ddd}, J=16.1,14.6,7.9 \mathrm{~Hz}, 2 \mathrm{H})$, $1.45-1.37(\mathrm{~m}, 2 \mathrm{H}), 1.14-1.05(\mathrm{~m}, 1 \mathrm{H}), 0.96(\mathrm{dd}, J=12.1,4.1 \mathrm{~Hz}, 1 \mathrm{H}), 0.94-0.88(\mathrm{~m}, 6 \mathrm{H}), 0.80$ $(\mathrm{dd}, J=7.0,0.9 \mathrm{~Hz}, 3 \mathrm{H}) .{ }^{13} \mathrm{C} \mathrm{NMR}\left(\mathrm{CDCl}_{3}\right) \delta 163.2,135.9,129.1,71.7,50.3,45.2,34.7,31.8$, $25.9,23.3,22.3,21.1,16.2$. Analytical data in accordance with those published [54].

(1R,2S,5R)-2-Isopropyl-5-methylcyclohexyl-12-methyl-9,10-dihydro-9,10-ethanoanthracene-12-car boxylate (14)

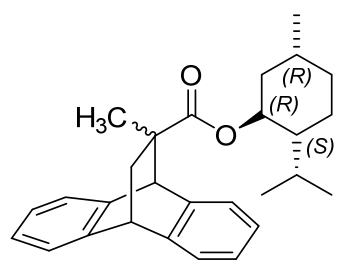

Synthesised according to general procedure B using $\mathrm{TiCl}_{4}(4.38 \mu \mathrm{L}, 3.93 \mathrm{mmol}),(1 R, 2 S, 5 R)$ 2-isopropyl-5-methylcyclohexyl methacrylate (13) (440 mg, $1.96 \mathrm{mmol}$ ) and anthracene (350 mg, $1.96 \mathrm{mmol}$ ). Purification by FCC (eluent, 10:1 PE/EtOAc] gave the anthracene ester derivative as a light-yellow oil $(400 \mathrm{mg}, 51 \%$, d.e. $>70 \%)$. LCMS $(\mathrm{m} / \mathrm{z}): 401.1$ [M $-\mathrm{H}]^{-}$. System C HPLC: $t_{\mathrm{R}} 2.204 \mathrm{~min},>95 \%$ purity $(214 \& 254 \mathrm{~nm}) .{ }^{1} \mathrm{H} \mathrm{NMR}\left(\mathrm{CDCl}_{3}\right) \delta$ 7.30-7.27 (m, 1H), 7.25-7.18 (m, 3H), 7.11-7.07 (m, 2H), 7.07-6.98 (m, 2H, H3), $4.48(\mathrm{td}$, $J=10.8,4.3 \mathrm{~Hz}, 1 \mathrm{H}), 4.38(\mathrm{~s}, 1 \mathrm{H}), 4.23(\mathrm{t}, J=2.6 \mathrm{~Hz}, 1 \mathrm{H}), 2.70(\mathrm{dd}, J=12.7,3.0 \mathrm{~Hz}, 1 \mathrm{H})$, $1.86(\mathrm{tt}, J=11.3,3.5 \mathrm{~Hz}, 1 \mathrm{H}), 1.67-1.57(\mathrm{~m}, 3 \mathrm{H}), 1.41-1.36(\mathrm{~m}, 2 \mathrm{H}), 1.36-1.32(\mathrm{~m}, 1 \mathrm{H}), 1.02$ $(\mathrm{s}, 3 \mathrm{H}), 0.98(\mathrm{dd}, J=13.1,3.2 \mathrm{~Hz}, 1 \mathrm{H}), 0.91(\mathrm{~d}, J=7.0 \mathrm{~Hz}, 3 \mathrm{H}), 0.88-0.85(\mathrm{~m}, 2 \mathrm{H}), 0.82(\mathrm{~d}$, $J=6.5 \mathrm{~Hz}, 3 \mathrm{H}), 0.68(\mathrm{~d}, J=6.9 \mathrm{~Hz}, 3 \mathrm{H}) .{ }^{13} \mathrm{C} \mathrm{NMR}\left(\mathrm{CDCl}_{3}\right) \delta 176.3,143.9,143.4,141.5,141.0$, $126.3,126.1,126.0,125.5,125.5,125.2,123.4,123.2,74.7,52.9,47.1,44.6,40.6,38.8,34.3,31.4$, $27.3,26.0,23.2,22.1,21.1,16.1$.

(R)-N-(2-Hydroxy-1-phenylethyl)methacrylamide [55] (16) 
<smiles>C=C(C)C(=O)N[C@@H](CO)c1ccccc1</smiles>

$\mathrm{KO}$ - $\mathrm{Bu}(3.27 \mathrm{~g}, 29.2 \mathrm{mmol})$ was dissolved in THF (100 mL; technical grade, containing ca. $0.2 \% \mathrm{H}_{2} \mathrm{O}$ ) with stirring in air at rt for $1 \mathrm{~min}$. Methyl methacrylate $(1.55 \mathrm{~mL}, 14.6 \mathrm{mmol})$ and $(R)$-2-amino-2-phenylethan-1-ol (2.00 g, $14.6 \mathrm{mmol})$ were added immediately and the mixture was stirred at $\mathrm{rt}$ for $1 \mathrm{~h}$. After evaporating the THF under reduced pressure, $\mathrm{H}_{2} \mathrm{O}$ $(75 \mathrm{~mL})$ and DCM $(75 \mathrm{~mL})$ were added and the organic layer was separated and dried $\left(\mathrm{Na}_{2} \mathrm{SO}_{4}\right)$. The solvent was evaporated under reduced pressure and residue was purified by FCC (eluent, 1:10 DCM/MeOH) to give the corresponding amide as a yellow / orange solid $(2.45 \mathrm{~g}, 89 \%)$. LCMS $(\mathrm{m} / \mathrm{z})$ : $206.1[\mathrm{M}+\mathrm{H}]^{+}$. System C HPLC: $t_{\mathrm{R}} 4.465 \mathrm{~min},>95 \%$ purity $(214 \& 254 \mathrm{~nm}) .{ }^{1} \mathrm{H}$ NMR $\left(\mathrm{CDCl}_{3}\right) \delta 7.38-7.33(\mathrm{~m}, 2 \mathrm{H}), 7.32-7.28(\mathrm{~m}, 3 \mathrm{H}), 6.57(\mathrm{~d}$, $J=5.6 \mathrm{~Hz}, 1 \mathrm{H}), 5.75(\mathrm{~s}, 1 \mathrm{H}), 5.37-5.36(\mathrm{~m}, 1 \mathrm{H}), 5.10(\mathrm{dt}, J=7.0,5.0 \mathrm{~Hz}, 1 \mathrm{H}), 3.89(\mathrm{~d}, J=4.9$ $\mathrm{Hz}, 2 \mathrm{H}), 2.96(\mathrm{~s}, 1 \mathrm{H}), 1.98-1.97(\mathrm{~m}, 3 \mathrm{H}) .{ }^{13} \mathrm{C} \mathrm{NMR}\left(\mathrm{CDCl}_{3}\right) \delta 168.9,139.8,139.2,129.0,128.0$, $126.8,120.3,66.6,56.1,18.8$. Analytical data in accordance with those published [55].

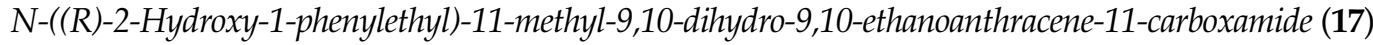<smiles>CC1(C(=O)N[C@@H](CO)c2ccccc2)c2ccccc2C1c1ccccc1</smiles>

Synthesised according to general procedure B using $\mathrm{TiCl}_{4}(1.45 \mathrm{~mL}, 13.0 \mathrm{mmol}),(R)-\mathrm{N}-(2-$ hydroxy-1-phenylethyl)methacrylamide $(1.34 \mathrm{~g}, 6.51 \mathrm{mmol})(\mathbf{1 6})$ and anthracene $(1.16 \mathrm{~g}$, $6.51 \mathrm{mmol})$. Residue chromatographed with 5:1 PE/EtOAc to afford a pair of diastereomers (2:1 ratio) as a transparent oil $(2.00 \mathrm{~g}, 80 \%)$. LCMS $(\mathrm{m} / \mathrm{z}): 384.2[\mathrm{M}+\mathrm{H}]^{+}$. System C HPLC: $t_{\mathrm{R}} 7.254 \mathrm{~min},>95 \%$ purity $(214 \& 254 \mathrm{~nm}) .{ }^{1} \mathrm{H}$ NMR $\left(401 \mathrm{MHz}, \mathrm{CDCl}_{3}\right) \delta 7.36-7.25(\mathrm{~m}, 12 \mathrm{H})$, 7.20-7.11 (m, 6H), 7.08-6.99 (m, 4H), $6.04(\mathrm{~s}, 0.5 \mathrm{H}), 5.75(\mathrm{~s}, 1 \mathrm{H}), 4.86(\mathrm{dt}, J=12.5,5.8 \mathrm{~Hz}$, $1.7 \mathrm{H}), 4.34(\mathrm{~d}, J=2.2 \mathrm{~Hz}, 3 \mathrm{H}), 3.80(\mathrm{dd}, J=4.6,2.4 \mathrm{~Hz}, 1 \mathrm{H}), 3.68(\mathrm{dd}, J=11.3,5.6 \mathrm{~Hz}, 1 \mathrm{H})$, $3.59(\mathrm{dd}, J=11.3,3.9 \mathrm{~Hz}, 1 \mathrm{H}), 2.58(\mathrm{dd}, J=12.8,3.0 \mathrm{~Hz}, 0.7 \mathrm{H}), 2.38(\mathrm{dd}, J=13.1,3.0 \mathrm{~Hz}, 1 \mathrm{H})$, $1.59(\mathrm{dd}, J=13.2,2.5 \mathrm{~Hz}, 1 \mathrm{H}), 1.55(\mathrm{dd}, J=13.4,3.0 \mathrm{~Hz}, 0.6 \mathrm{H}), 1.10(\mathrm{~s}, J=2.6 \mathrm{~Hz}, 1.4 \mathrm{H}), 1.09$ $(\mathrm{s}, 3 \mathrm{H})$.

(R)-4,4-Dimethyl-2-oxotetrahydrofuran-3-yl methacrylate ((R)-19)<smiles>C=C(C)C(=O)O[C@H]1C(=O)OCC1(C)C</smiles>

Synthesised according to general procedure A using methacrylic acid $(1.49 \mathrm{~g}, 17.3 \mathrm{mmol})$, (R)-3-hydroxy-4,4-dimethyldihydrofuran-2(3H)-one (2.25 g, $17.3 \mathrm{mmol})$, EDC (3.31 g, $17.3 \mathrm{mmol}$ ) and DMAP (106 mg, $864 \mu \mathrm{mol})$. Purification by FCC (eluent, DCM) gave the title compound as a transparent oil $(3.55 \mathrm{~g}, 67 \%)$. LCMS $(\mathrm{m} / \mathrm{z}): 221.1[\mathrm{M}+\mathrm{Na}]^{+}$. System C HPLC: $t_{\mathrm{R}} 6.010 \mathrm{~min},>95 \%$ purity $(214 \& 254 \mathrm{~nm}) .{ }^{1} \mathrm{H} \mathrm{NMR}\left(\mathrm{CDCl}_{3}\right) \delta 6.26-6.15(\mathrm{~m}, 1 \mathrm{H})$, $5.68(\mathrm{dd}, J=2.6,1.2 \mathrm{~Hz}, 1 \mathrm{H}), 5.41(\mathrm{~d}, J=0.8 \mathrm{~Hz}, 1 \mathrm{H}), 4.09-4.01(\mathrm{~m}, 2 \mathrm{H}), 1.98(\mathrm{dd}, J=1.7$, $0.8 \mathrm{~Hz}, 3 \mathrm{H}), 1.21(\mathrm{~s}, 3 \mathrm{H}), 1.13(\mathrm{~s}, 3 \mathrm{H}) .{ }^{13} \mathrm{C} \mathrm{NMR}\left(\mathrm{CDCl}_{3}\right) \delta$ 172.4, 165.9, 135.1, 127.5, 76.2, $75.2,23.1,19.9,18.2$.

(S)-4,4-Dimethyl-2-oxotetrahydrofuran-3-yl methacrylate ((S)-19)<smiles>C=C(C)C(=O)O[C@H]1C(=O)OCC1(C)C</smiles> 
Synthesised according to general procedure A using methacrylic acid $(2.32 \mathrm{~g}, 26.9 \mathrm{mmol})$, (S)-3-hydroxy-4,4-dimethyldihydrofuran-2(3H)-one (3.50 g, $26.9 \mathrm{mmol})$, EDC (5.16 g, $26.9 \mathrm{mmol})$, and DMAP (164 mg, $1.34 \mathrm{mmol}$ ). Purification by FCC (eluent, DCM) gave the title compound as a transparent oil $(1.05 \mathrm{~g}, 69 \%)$. LCMS $(\mathrm{m} / \mathrm{z}): 221.1[\mathrm{M}+\mathrm{Na}]^{+}$. System C HPLC: $t_{\mathrm{R}} 6.010 \mathrm{~min},>95 \%$ purity $(214 \& 254 \mathrm{~nm}) .{ }^{1} \mathrm{H}$ NMR $\left(\mathrm{CDCl}_{3}\right) \delta 6.26-6.15(\mathrm{~m}, 1 \mathrm{H})$, $5.68(\mathrm{dd}, J=2.6,1.2 \mathrm{~Hz}, 1 \mathrm{H}), 5.41(\mathrm{~d}, J=0.8 \mathrm{~Hz}, 1 \mathrm{H}), 4.09-4.01(\mathrm{~m}, 2 \mathrm{H}), 1.98(\mathrm{dd}, J=1.7$, $0.8 \mathrm{~Hz}, 3 \mathrm{H}), 1.21(\mathrm{~s}, 3 \mathrm{H}), 1.13(\mathrm{~s}, 3 \mathrm{H}) .{ }^{13} \mathrm{C} \mathrm{NMR}\left(\mathrm{CDCl}_{3}\right) \delta$ 172.4, 165.9, 135.1, 127.5, 76.2, $75.2,23.1,19.9,18.2$.

(R)-4,4-Dimethyl-2-oxotetrahydrofuran-3-yl-(S)-12-methyl-9,10-dihydro-9,10-ethanoanthracene-12-car boxylate $((S)-20)$

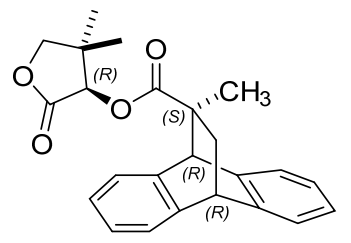

Synthesised according to general procedure B using $\mathrm{TiCl}_{4}(2.39 \mathrm{~mL}, 21.8 \mathrm{mmol}),(R)-$ 4,4-dimethyl-2-oxotetrahydrofuran-3-yl methacrylate $((R)-19)(2.06 \mathrm{~g}, 10.4 \mathrm{mmol})$ and anthracene $(1.85 \mathrm{~g}, 10.4 \mathrm{mmol})$. Purification by FCC (eluent, DCM) afforded the title compound as a brown solid. Recrystallization from $\mathrm{EtOH}$ gave white crystals $(3.25 \mathrm{~g}, 83 \%$, d.e. $\sim 90 \%)$. LCMS $(\mathrm{m} / \mathrm{z}): 399.1[\mathrm{M}+\mathrm{Na}]^{+}$. System C HPLC: $t_{\mathrm{R}} 8.320 \mathrm{~min},>95 \%$ purity $(214$ \& $254 \mathrm{~nm}) .{ }^{1} \mathrm{H}$ NMR $\left(401 \mathrm{MHz}, \mathrm{CDCl}_{3}\right) \delta 7.33(\mathrm{dt}, J=5.4,3.3 \mathrm{~Hz}, 1 \mathrm{H}), 7.30-7.26(\mathrm{~m}, 2 \mathrm{H})$, 7.24-7.21 (m, 1H), 7.16-7.10 (m, 2H), 7.10-7.02 (m, 2H), $5.18(\mathrm{~s}, 1 \mathrm{H}), 4.40(\mathrm{~s}, 1 \mathrm{H}), 4.30(\mathrm{t}$, $J=2.7 \mathrm{~Hz}, 1 \mathrm{H}), 4.04(\mathrm{~d}, J=9.0 \mathrm{~Hz}, 1 \mathrm{H}), 3.97(\mathrm{~d}, J=9.0 \mathrm{~Hz}, 1 \mathrm{H}), 2.76(\mathrm{dd}, J=12.8,3.0 \mathrm{~Hz}$, $1 \mathrm{H}), 1.50(\mathrm{dd}, J=12.8,2.6 \mathrm{~Hz}, 1 \mathrm{H}), 1.25(\mathrm{~s}, 3 \mathrm{H}), 1.18(\mathrm{~s}, 3 \mathrm{H}), 1.17(\mathrm{~s}, 3 \mathrm{H}) .{ }^{13} \mathrm{C} \mathrm{NMR}\left(\mathrm{CDCl}_{3}\right)$ $\delta$ 175.6, 172.1, 143.7, 143.5, 141.2, 140.4, 126.6, 126.6, 125.7, 125.5, 124.8, 123.9, 123.4, 76.2, 75.5, 52.6, 49.0, 44.4, 39.2, 27.2, 23.0, 20.3.

(S)-4,4-Dimethyl-2-oxotetrahydrofuran-3-yl-(R)-12-methyl-9,10-dihydro-9,10-ethanoanthracene-12-car boxylate $((R)-20)$

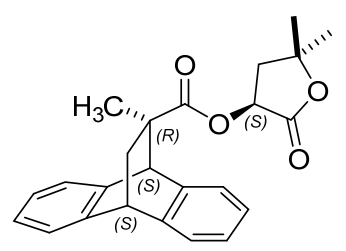

Synthesised according to general procedure B using $\mathrm{TiCl}_{4}(1.61 \mathrm{~mL}, 14.7 \mathrm{mmol}),(S)$ 4,4-dimethyl-2-oxotetrahydrofuran-3-yl methacrylate ((S)-19) $(1.39 \mathrm{~g}, 7.01 \mathrm{mmol})$ and anthracene $(1.25 \mathrm{~g}, 7.01 \mathrm{mmol})$. Purification by FCC (eluent, DCM) afforded the title compound as a beige solid $(2.15 \mathrm{~g}, 82 \%$, d.e. $~ 83 \%)$ LCMS $(\mathrm{m} / \mathrm{z}): 399.1[\mathrm{M}+\mathrm{Na}]^{+}$. System C HPLC: $t_{\mathrm{R}} 8.320 \mathrm{~min},>95 \%$ purity $(214 \& 254 \mathrm{~nm}) .{ }^{1} \mathrm{H}$ NMR $\left(\mathrm{CDCl}_{3}\right) \delta 7.33(\mathrm{dt}, J=5.4$, $3.3 \mathrm{~Hz}, 1 \mathrm{H}), 7.30-7.26(\mathrm{~m}, 2 \mathrm{H}), 7.24-7.21(\mathrm{~m}, 1 \mathrm{H}), 7.16-7.10(\mathrm{~m}, 2 \mathrm{H}), 7.10-7.02(\mathrm{~m}, 2 \mathrm{H}), 5.18$ $(\mathrm{s}, 1 \mathrm{H}), 4.40(\mathrm{~s}, 1 \mathrm{H}), 4.30(\mathrm{t}, J=2.7 \mathrm{~Hz}, 1 \mathrm{H}), 4.04(\mathrm{~d}, J=9.0 \mathrm{~Hz}, 1 \mathrm{H}), 3.97(\mathrm{~d}, J=9.0 \mathrm{~Hz}, 1 \mathrm{H})$, $2.76(\mathrm{dd}, J=12.8,3.0 \mathrm{~Hz}, 1 \mathrm{H}), 1.50(\mathrm{dd}, J=12.8,2.6 \mathrm{~Hz}, 1 \mathrm{H}), 1.25(\mathrm{~s}, 3 \mathrm{H}), 1.18(\mathrm{~s}, 3 \mathrm{H}), 1.17(\mathrm{~s}$, $3 \mathrm{H}) .{ }^{13} \mathrm{C} \mathrm{NMR}\left(\mathrm{CDCl}_{3}\right) \delta 175.6,172.1,143.7,143.5,141.2,140.4,126.6,126.6,125.7,125.5$, 124.8, 123.9, 123.4, 76.2, 75.5, 52.6, 49.0, 44.4, 39.2, 27.2, 23.0, 20.3.

(S)-12-Methyl-9,10-dihydro-9,10-ethanoanthracene-12-carboxylic acid ((S)-21)

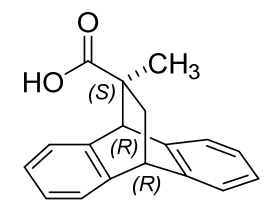


Synthesised according to general procedure $C$ using $(R)$-4,4-Dimethyl-2-oxotetrahydrofuran3-yl-(S)-12-methyl-9,10-dihydro-9,10-ethanoanthracene-12-carboxylate ((S)-20) (3.00 g, $7.97 \mathrm{mmol})$ and $\mathrm{NaOH}(956 \mathrm{mg}, 23.9 \mathrm{mmol})$. The aqueous phase was extracted with $\mathrm{DCM}$, and the organic extracts were dried $\left(\mathrm{Na}_{2} \mathrm{SO}_{4}\right)$ and evaporated to dryness to afford the desired acid as a white foam $(2.05 \mathrm{~g}, 95 \%$, e.e. $\sim 88 \%)$. $[\alpha]_{\mathrm{D}}{ }^{25}=-24.9^{\circ}\left(c 1.0, \mathrm{CHCl}_{3}\right)$, ${ }^{\text {lit }}[\alpha]_{\mathrm{D}}{ }^{20}=-26.7^{\circ}\left(c 1.08, \mathrm{CHCl}_{3}\right)$ [39], LCMS $(m / z): 263.1[\mathrm{M}-\mathrm{H}]^{-}$. System C HPLC: $t_{\mathrm{R}}$ $7.181 \mathrm{~min},>95 \%$ purity $(214 \& 254 \mathrm{~nm})$. Analytical data including ${ }^{1} \mathrm{H}$ NMR and ${ }^{13} \mathrm{C}$ NMR spectra are in accordance with those reported by Camps et al. [39] (R)-12-Methyl-9,10-dihydro-9,10-ethanoanthracene-12-carboxylic acid ((R)-21)

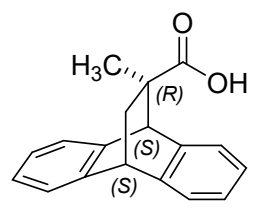

Synthesised according to general procedure $C$ using (S)-4,4-Dimethyl-2-oxotetrahydrofuran3-yl-(S)-12-methyl-9,10-dihydro-9,10-ethanoanthracene-12-carboxylate $((R)-20)$ (1.40 g, $3.72 \mathrm{mmol})$ and $\mathrm{NaOH}(446 \mathrm{mg}, 11.2 \mathrm{mmol})$. The aqueous phase was extracted with $\mathrm{DCM}$, and the organic extracts were dried $\left(\mathrm{Na}_{2} \mathrm{SO}_{4}\right)$ and evaporated to dryness to afford the desired acid as a white solid (956 mg, 98\%, e.e. $\sim 83 \%)$. $[\alpha]_{\mathrm{D}}{ }^{25}=+24.1^{\circ}\left(c 1.0, \mathrm{CHCl}_{3}\right)$, LCMS $(m / z)$ : $263.1[\mathrm{M}-\mathrm{H}]^{-}$. System C HPLC: $t_{\mathrm{R}} 7.181 \mathrm{~min},>95 \%$ purity $(214 \& 254$ nm). ${ }^{1} \mathrm{H}$ NMR $\left(\mathrm{CDCl}_{3}\right) \delta$ 7.31-7.28 (m, 1H), 7.27-7.23 (m, 3H), 7.23-7.19 (m, 1H), $7.12(\mathrm{ddd}$, $J=6.1,5.6,3.7 \mathrm{~Hz}, 2 \mathrm{H}), 7.08(\mathrm{dd}, J=7.2,1.5 \mathrm{~Hz}, 1 \mathrm{H}) 7.06-7.01(\mathrm{~m}, 1 \mathrm{H}), 4.37(\mathrm{~s}, 1 \mathrm{H}), 4.26(\mathrm{t}$, $J=2.7 \mathrm{~Hz}, 1 \mathrm{H}), 2.62(\mathrm{dd}, J=12.7,3.0 \mathrm{~Hz}, 1 \mathrm{H}), 1.40(\mathrm{dd}, J=12.7,2.5 \mathrm{~Hz}, 1 \mathrm{H}), 1.07(\mathrm{~s}, 3 \mathrm{H})$. ${ }^{13} \mathrm{C}$ NMR $\left(\mathrm{CDCl}_{3}\right) \delta 181.7,143.6,143.3,141.3,140.5,126.5,126.3,126.2,125.8,125.7,125.2$, $123.5,123.3,52.6,48.5,44.5,38.7,26.9$.

(9S,10R,12R)-N-(2,6-Dichloro-3-methylphenyl)-12-methyl-9,10-dihydro-9,10-ethanoanthracene-12-car boxamide ((S)-2)

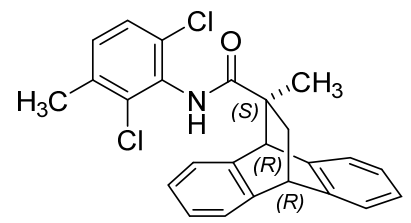

Synthesised according to general procedure D using (S)-12-methyl-9,10-dihydro-9,10-

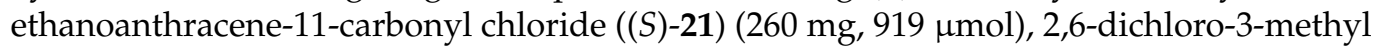
aniline $(162 \mathrm{mg}, 920 \mu \mathrm{mol})$, and DMAP $(56.2 \mathrm{mg}, 460 \mu \mathrm{mol})$. Purification by FCC (eluent, 1:10 EtOAc/PE) afforded the title compound as a white solid (75 mg, 19\%, e.e. $90 \%)$. LCMS $(m / z): 446.1[\mathrm{M}+\mathrm{Na}]^{+}, 423.1[\mathrm{M}+\mathrm{H}]^{+}$. System C HPLC: $t_{\mathrm{R}} 8.496 \mathrm{~min},>95 \%$ purity $(214$ \& $254 \mathrm{~nm})$. HRMS $(m / z): \mathrm{C}_{25} \mathrm{H}_{21} \mathrm{C}_{12} \mathrm{NO}$ : requires $422.1083[\mathrm{M}+\mathrm{H}]^{+}$; found $422.1073 .{ }^{1} \mathrm{H}$ $\operatorname{NMR}\left(\mathrm{CDCl}_{3}\right) \delta$ 7.40-7.37 (m, 1H), 7.34-7.31 (m, 1H), 7.30-7.25 (m, 2H), 7.18-7.11 (m, 3H), $7.08-7.01(\mathrm{~m}, 3 \mathrm{H}), 6.89(\mathrm{~s}, 1 \mathrm{H}), 4.52(\mathrm{~s}, 1 \mathrm{H}), 4.34(\mathrm{t}, J=2.6 \mathrm{~Hz}, 1 \mathrm{H}), 2.64(\mathrm{dd}, J=12.5,2.8 \mathrm{~Hz}$, $1 \mathrm{H}), 2.29(\mathrm{~s}, 3 \mathrm{H}), 1.66(\mathrm{dd}, J=12.4,2.7 \mathrm{~Hz}, 1 \mathrm{H}), 1.18(\mathrm{~s}, 3 \mathrm{H}) .{ }^{13} \mathrm{C} \mathrm{NMR}\left(\mathrm{CDCl}_{3}\right) \delta 174.7,143.3$, 143.2, 141.5, 141.4, 136.1, 133.8, 132.2, 130.8, 129.6, 127.4, 126.5, 126.4, 126.2, 125.9, 125.9, $125.7,123.5,123.2,52.7,49.2,44.7,40.3,28.3,20.5$.

(9R,10S,12S)-N-(2,6-Dichloro-3-methylphenyl)-12-methyl-9,10-dihydro-9,10-ethanoanthracene-12-car boxamide $((R)-2)$

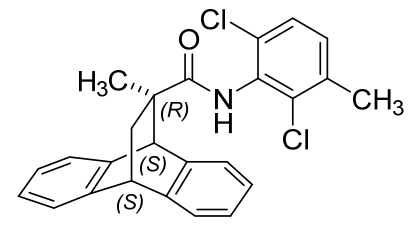


Synthesised according to general procedure D using (R)-12-methyl-9,10-dihydro-9,10ethanoanthracene-11-carbonyl chloride ((R)-21) (135 mg, $477 \mu \mathrm{mol}), 2,6$-dichloro-3-methy laniline ( $84.1 \mathrm{mg}, 477 \mu \mathrm{mol})$, and DMAP $(29.1 \mathrm{mg}, 239 \mu \mathrm{mol})$. Purification by FCC (eluent, 1:10 EtOAc/PE) afforded the title compound as a white solid ( $50 \mathrm{mg}, 25 \%$, e.e. $84 \%$ ). LCMS $(m / z): 446.1[\mathrm{M}+\mathrm{Na}]^{+}, 423.1[\mathrm{M}+\mathrm{H}]^{+}$. System C HPLC: $t_{\mathrm{R}} 8.496 \mathrm{~min},>95 \%$ purity $(214$ \& $254 \mathrm{~nm})$. HRMS $(m / z): \mathrm{C}_{25} \mathrm{H}_{21} \mathrm{C}_{12} \mathrm{NO}$ : requires $422.1083[\mathrm{M}+\mathrm{H}]^{+}$; found $422.1073 .{ }^{1} \mathrm{H}$ NMR $\left(\mathrm{CDCl}_{3}\right) \delta 7.40-7.37(\mathrm{~m}, 1 \mathrm{H}), 7.34-7.31(\mathrm{~m}, 1 \mathrm{H}), 7.30-7.25(\mathrm{~m}, 2 \mathrm{H}), 7.18-7.11(\mathrm{~m}, 3 \mathrm{H})$, $7.08-7.01(\mathrm{~m}, 3 \mathrm{H}), 6.89(\mathrm{~s}, 1 \mathrm{H}), 4.52(\mathrm{~s}, 1 \mathrm{H}), 4.34(\mathrm{t}, J=2.6 \mathrm{~Hz}, 1 \mathrm{H}), 2.64(\mathrm{dd}, J=12.5,2.8 \mathrm{~Hz}$, $1 \mathrm{H}), 2.29(\mathrm{~s}, 3 \mathrm{H}), 1.66(\mathrm{dd}, J=12.4,2.7 \mathrm{~Hz}, 1 \mathrm{H}), 1.18(\mathrm{~s}, 3 \mathrm{H}) .{ }^{13} \mathrm{C} \mathrm{NMR}\left(\mathrm{CDCl}_{3}\right) \delta 174.7,143.3$, 143.2, 141.5, 141.4, 136.1, 133.8, 132.2, 130.8, 129.6, 127.4, 126.5, 126.4, 126.2, 125.9, 125.9, $125.7,123.5,123.2,52.7,49.2,44.7,40.3,28.3,20.5$.

\subsection{Pharmacological Characterisation}

\subsubsection{Materials}

Dulbecco's modified Eagle's medium, Flp-In CHO cells, and hygromycin B (Invitrogen, Carlsbad, CA, USA). Fetal bovine serum (FBS) (ThermoTrace, Melbourne, VIC, Australia). All other reagents (Sigma Aldrich, St. Louis, MO, USA).

\subsubsection{General Cell Culture}

FlpIn Chinese Hamster Ovary (CHO) cells (Invitrogen, Carlsbad, CA, USA) were grown in DMEM supplemented with $10 \% \mathrm{FBS}$ and maintained at $37^{\circ} \mathrm{C}$ in a humidified incubator $\left(5 \% \mathrm{CO}_{2}\right)$. The Flp-In-CHO cells were transfected with the pOG44 vector encoding Flp recombinase and the pDEST vector encoding the $D_{2 L} R$ or the $h D_{1} R$ at a ratio of 9:1 using PEI as transfection reagent. Following transfection $(24 \mathrm{~h})$, cells were subcultured and the medium supplemented with $700 \mathrm{mg} / \mathrm{mL}$ HygroGold (Invivogen) as selection agent, to obtain cells stably expressing the $\mathrm{D}_{1} \mathrm{R}$ or $\mathrm{D}_{2 \mathrm{~L}} \mathrm{R}$. FlpIn Chinese Hamster Ovary CHO cells stably expressing the $\mathrm{hD}_{1} \mathrm{R}$ or $\mathrm{hD}_{2 \mathrm{~L}} \mathrm{R}$ were grown and maintained in Dulbecco's modified Eagle's medium (DMEM) supplemented with $10 \%$ FBS, and $200 \mu \mathrm{g} / \mathrm{mL}$ of Hygromycin-B, and maintained at $37^{\circ} \mathrm{C}$ in a humidified incubator $\left(5 \% \mathrm{CO}_{2}\right)$.

\section{Cell Culture and Transfection for cAMP Assay}

FlpIn $\mathrm{CHO}$ cells stably expressing the $\mathrm{hD}_{1} \mathrm{R}$ were maintained in DMEM supplemented with $5 \%$ fetal calf serum and $0.2 \mathrm{mg} / \mathrm{mL}$ hygromycin at $37^{\circ} \mathrm{C}$ in a humidified incubator $(5 \%$ $\mathrm{CO}_{2}$ ). For transfection, the cells were grown in $10 \mathrm{~cm}$ culture dishes until $60 \%$ confluent. A mixture of $4 \mu \mathrm{g}$ plasmid DNA containing BRET-based cAMP (CAMYEL) biosensor construct [52] and $25 \mu \mathrm{g} 20 \mathrm{kDa}$ linear PEI in $500 \mu \mathrm{L} 150 \mathrm{mM} \mathrm{NaCl}$ was added into a dish of cells.

\subsection{3. cAMP Assay Measurement}

Cellular cAMP levels were measured with the CAMYEL BRET-based biosensor for cAMP [52]. One day following transfection, cells were trypsinised and seeded in white 96-well microplates, cultured for an additional day, rinsed $(\times 2)$ with Hank's Balanced Salt Solution (HBSS), then incubated in fresh HBSS. For the $\mathrm{D}_{1} \mathrm{R}$ functional assay, the cells were stimulated with DA together with addition of the modulators. The BRET signals were measured using a BMG Lumistar counter 30 min after stimulation. For the $D_{2} R$ functional assay, cells were stimulated with DA in the presence of $10 \mu \mathrm{M}$ forskolin (final concentration). DA and modulators were added $15 \mathrm{~min}$ prior to stimulation and BRET signals were measured using a BMG Lumistar counter $30 \mathrm{~min}$ after stimulation. The BRET signal (BRET ratio) was detected at 445-505 $\mathrm{nm}$ and 505-565 $\mathrm{nm}$ using a LUMIstar Omega instrument (BMG LabTech, Offenburg, Germany), and quantified by calculating the ratio of light emitted at $535 \pm 30 \mathrm{~nm}$ (YFP) to light emitted at $475 \pm 30 \mathrm{~nm}$ (RLuc). 


\subsubsection{Data Analysis of Allsotery}

Simulations, statistical analyses and computerized nonlinear regression were performed using Prism 6.0 (GraphPad Prism 6.0b Software, San Diego, CA, USA).

Analysis of functional data. All concentration-response data were fitted to the following modified four-parameter Hill equation in order to derive potency estimates [56].

$$
E=\text { Basal }+\frac{\left(E_{\max }-B a s a l\right) \cdot[A]^{n H}}{\left[A^{n H}\right]+E C_{50}^{n H}}
$$

where $E=$ the effect of the system; $n H=$ Hill slope; $E C_{50}=[A]$ (concentration of agonist) that provides the midpoint response between basal and maximal effect of DA or other agonists $\left(E_{\max }\right)$, which are the lower and upper asymptotes of the response, respectively.

To determine the mode of interaction of compounds $\mathbf{2}$, and optical isomers of $\mathbf{2}$ at the $\mathrm{D}_{1} \mathrm{R}$ in relation to the agonist DA, all data were analyzed using a complete operational model of allosterism and agonism according to Equation (2) [34]

$$
E=\frac{E_{m}\left(\tau_{A}[A]\left(K_{B}+\alpha \beta[B]\right)+\tau_{B}[B] K_{A}\right)^{n H}}{\left([A] K_{B}+K_{A} K_{B}+K_{A}[B]+\alpha[A][B]\right)^{n H}+\left(\tau_{A}[A]\left(K_{B}+\alpha \beta[B]\right)+\tau_{B}[B] K_{A}\right)^{n H}}
$$

where $E_{m}=$ maximum possible cellular response, $[A] \&[B]=$ concentrations of orthosteric and allosteric ligands, respectively, $K_{A} \& K_{B}=$ equilibrium dissociation constants of orthosteric and allosteric ligands, respectively, $\tau_{A} \& \tau_{B}=$ operational measures of orthosteric and allosteric ligand efficacy (which incorporate both signal efficiency and receptor density), respectively, $\alpha=$ binding cooperativity parameter between orthosteric and allosteric ligand, and $\beta=$ magnitude of the allosteric effect of modulator on efficacy of orthosteric agonist.

The $K_{A}$ for DA was determined through receptor depletion by phenoxybenzamine alkylation as the proportional relationship of $R_{T}$ to measured $\tau$ whilst $K_{A}$ is invariant with receptor depletion. Thus, unique estimates of $K_{A}$ could be measured by direct fitting of the operational model to the family of concentration-response curve for DA $[57,58]$. A series of cAMP inhibition assays were conducted in cells which were pre-treated with phenoxybenzamine (an alkylating agent which is used to inhibit high affinity orthosteric interactions at the $\left.\mathrm{D}_{2} \mathrm{R}\right)$ [59]. The data for DA evaluated in the presence of the alkylating agent were then fit to an operational model of receptor depletion in order to determine values of $K_{A}$ and $\tau_{A}\left(\log K_{A}=-5.78 \pm 0.16, \log \tau_{A}=1.84 \pm 0.16\right)$. These data were used to constrain values of $K_{A}$ and $\tau_{A}$ when we fitted the operational model of allostery (Equation (2)) to functional data. The value of the Hill slope $(n H)$ was fixed to unity. The logarithms of affinity and cooperativity values are normally distributed, whereas the absolute values (antilogarithms) are not, and therefore all statistical analyses were performed on the logarithmic values. However, for ease of interpretation, allosteric parameter antilogarithms are highlighted in the main text [60].

\section{Conclusions}

In this study, we describe the first reported enantioenrichment of optical isomers of rac2 using chiral auxiliaries derived from enantiomers of 3-hydroxy-4,4-dimethyldihydrofuran$2(3 H)$-one and their pharmacological characterisation. Interestingly, $(R)-2$ was shown to display 4-fold lower positive cooperativity with DA as compared to (S)-2 and a 7-fold lower affinity for the $D_{1} R$. Our findings illustrate the importance of further investigation into asymmetric syntheses of analogues of $\mathbf{2}$ and/or isolation of optically pure analogues as part of future SAR efforts aimed at developing enhanced $D_{1} R$ PAMs based on this scaffold.

Supplementary Materials: The following are available online. Figure S1: Chiral HPLC chromatogram for Compound 5, Figure S2: Chiral HPLC chromatogram for Compound (S)-21, Figure S3: Chiral HPLC chromatogram for Compound (R)-21, Figures S4-S7: HPLC \& chiral HPLC chromatograms, ${ }^{1} \mathrm{H} \&{ }^{13} \mathrm{C}$ NMR spectra for 2, Figure S8: HPLC chromatogram (MeOH blank), Figures S9-S12: 
HPLC \& chiral HPLC chromatograms, ${ }^{1} \mathrm{H} \&{ }^{13} \mathrm{C}$ NMR spectra for $(S)-2$, Figures S13-S16: HPLC \& chiral HPLC chromatograms, ${ }^{1} \mathrm{H} \&{ }^{13} \mathrm{C}$ NMR spectra for $(R)-\mathbf{2}$.

Author Contributions: T.J.F. synthesized the target compounds and carried out their spectroscopic identification. P.J.S. and B.C. contributed to the spectroscopic identification. T.J.F. and J.R.L. performed the in vitro pharmacological evaluation of the synthesized target compounds. J.R.L., P.J.S. and B.C. proposed the work and T.J.F. prepared the manuscript for publication. All authors have read and agreed to the published version of the manuscript.

Funding: This research was supported by a National Health and Medical Research Council (NHMRC) of Australia under project grant no. APP1049564.

Data Availability Statement: Data is contained within the article or Supplementary Materials.

Acknowledgments: The authors would like to thank the Australian government for their support through an Australian Postgraduate Award to T.J.F.

Conflicts of Interest: The authors declare no conflict of interest.

Sample Availability: Samples of the compounds are available from the authors.

\section{References}

1. Ibrahim, H.M.; Tamminga, C.A. Schizophrenia: Treatment targets beyond monoamine systems. Annu. Rev. Pharmacol. Toxicol. 2011, 51, 189-209. [CrossRef]

2. Van Os, J.; Kapur, S. Schizophrenia. Lancet 2009, 374, 635-645. [CrossRef]

3. Rosen, W.G.; Mohs, R.C.; Johns, C.A.; Small, N.S.; Kendler, K.S.; Horvath, T.B.; Davis, K.L. Positive and negative symptoms in schizophrenia. Psychiatry Res. 1984, 13, 277-284. [CrossRef]

4. Bowie, C.R.; Harvey, P.D. Cognitive deficits and functional outcome in schizophrenia. Neuropsychiatr. Dis. Treat. 2006, 2, 531-536. [CrossRef] [PubMed]

5. O'Tuathaigh, C.M.P.; Moran, P.M.; Zhen, X.C.; Waddington, J.L. Translating advances in the molecular basis of schizophrenia into novel cognitive treatment strategies. Br. J. Pharmacol. 2017, 174, 3173-3190. [CrossRef]

6. Leucht, S.; Corves, C.; Arbter, D.; Engel, R.R.; Li, C.; Davis, J.M. Second-generation versus first-generation antipsychotic drugs for schizophrenia: A meta-analysis. Lancet 2009, 373, 31-41. [CrossRef]

7. Koster, L.S.; Carbon, M.; Correll, C.U. Emerging drugs for schizophrenia: An update. Expert Opin. Emerg. Drugs 2014, 19, 511-531. [CrossRef]

8. Curtis, C.E.; D’Esposito, M. Persistent activity in the prefrontal cortex during working memory. Trends Cogn. Sci. 2003, 7, 415-423. [CrossRef]

9. Davis, K.L.; Kahn, R.S.; Ko, G.; Davidson, M. Dopamine in schizophrenia: A review and reconceptualization. Am. J. Psychiatry 1991, 148, 1474-1486. [CrossRef]

10. Weinberger, D.R. Implications of normal brain development for the pathogenesis of schizophrenia. Arch. Gen. Psychiatry 1987, 44, 660-669. [CrossRef]

11. Brozoski, T.J.; Brown, R.M.; Rosvold, H.E.; Goldman, P.S. Cognitive deficit caused by regional depletion of dopamine in prefrontal cortex of rhesus monkey. Science 1979, 205, 929-932. [CrossRef] [PubMed]

12. Sawaguchi, T.; Goldman-Rakic, P.S. The role of D1-dopamine receptor in working memory: Local injections of dopamine antagonists into the prefrontal cortex of rhesus monkeys performing an oculomotor delayed-response task. J. Neurophysiol. 1994, 71, 515-528. [CrossRef] [PubMed]

13. Sawaguchi, T.; Goldman-Rakic, P.S. D1 dopamine receptors in prefrontal cortex: Involvement in working memory. Science 1991, 251, 947-950. [CrossRef]

14. Arnsten, A.F.; Cai, J.X.; Murphy, B.L.; Goldman-Rakic, P.S. Dopamine D1 receptor mechanisms in the cognitive performance of young adult and aged monkeys. Psychopharmacology 1994, 116, 143-151. [CrossRef] [PubMed]

15. Locke, T.M.; Soden, M.E.; Miller, S.M.; Hunker, A.; Knakal, C.; Licholai, J.A.; Dhillon, K.S.; Keene, C.D.; Zweifel, L.S.; Carlson, E.S. Dopamine D1 receptor-Positive neurons in the lateral nucleus of the cerebellum contribute to cognitive behavior. Biol. Psychiatry 2018. [CrossRef]

16. Abi-Dargham, A.; Moore, H. Prefrontal DA transmission at D1 receptors and the pathology of schizophrenia. Neuroscientist 2003, 9, 404-416. [CrossRef] [PubMed]

17. Vijayraghavan, S.; Wang, M.; Birnbaum, S.G.; Williams, G.V.; Arnsten, A.F. Inverted-U dopamine D1 receptor actions on prefrontal neurons engaged in working memory. Nat. Neurosci. 2007, 10, 376-384. [CrossRef] [PubMed]

18. Mailman, R.; Huang, X.; Nichols, D.E. Parkinson's disease and D1 dopamine receptors. Curr. Opin. Investig. Drugs 2001, 2, 1582-1591.

19. Starr, M.S.; Starr, B.S. Seizure promotion by D1 agonists does not correlate with other dopaminergic properties. J. Neural Transm. Parkinson's Dis. Dement. Sect. 1993, 6, 27-34. [CrossRef] [PubMed] 
20. Arnsten, A.F.; Girgis, R.R.; Gray, D.L.; Mailman, R.B. Novel Dopamine Therapeutics for Cognitive Deficits in Schizophrenia. Biol. Psychiatry 2017, 81, 67-77. [CrossRef] [PubMed]

21. Amenta, F.; Ferrante, F.; Ricci, A. Pharmacological Characterisation and Autoradiographic Localisation of Dopamine Receptor Subtypes in the Cardiovascular System and in the Kidney. Hypertens. Res. 1995, 18, S23-S27. [CrossRef]

22. Ryman-Rasmussen, J.P.; Griffith, A.; Oloff, S.; Vaidehi, N.; Brown, J.T.; Goddard, W.A., 3rd; Mailman, R.B. Functional selectivity of dopamine D1 receptor agonists in regulating the fate of internalized receptors. Neuropharmacology 2007, 52, 562-575. [CrossRef] [PubMed]

23. Gulwadi, A.G.; Korpinen, C.D.; Mailman, R.B.; Nichols, D.E.; Sit, S.Y.; Taber, M.T. Dinapsoline: Characterization of a D1 dopamine receptor agonist in a rat model of Parkinson's disease. J. Pharmacol. Exp. Ther. 2001, 296, 338-344.

24. Bruns, R.F.; Mitchell, S.N.; Wafford, K.A.; Harper, A.J.; Shanks, E.A.; Carter, G.; O’Neill, M.J.; Murray, T.K.; Eastwood, B.J.; Schaus, J.M.; et al. Preclinical profile of a dopamine D1 potentiator suggests therapeutic utility in neurological and psychiatric disorders. Neuropharmacology 2018, 128, 351-365. [CrossRef]

25. Svensson, K.A.; Heinz, B.A.; Schaus, J.M.; Beck, J.P.; Hao, J.; Krushinski, J.H.; Reinhard, M.R.; Cohen, M.P.; Hellman, S.L.; Getman, B.G.; et al. An allosteric potentiator of the dopamine D1 receptor increases locomotor activity in human D1 knock-in mice without causing stereotypy or tachyphylaxis. J. Pharmacol. Exp. Ther. 2017, 360, 117-128. [CrossRef]

26. Luderman, K.D.; Conroy, J.L.; Free, R.B.; Southall, N.; Ferrer, M.; Sanchez-Soto, M.; Moritz, A.E.; Willette, B.K.A.; Fyfe, T.J.; Jain, P.; et al. Identification of positive allosteric modulators of the D1 dopamine receptor that act at diverse binding sites. Mol. Pharmacol. 2018, 94, 1197-1209. [CrossRef]

27. Hall, A.; Provins, L.; Valade, A. Novel strategies to activate the dopamine $\mathrm{D}_{1}$ receptor: Recent advances in orthosteric agonism and positive allosteric modulation. J. Med. Chem. 2019, 62, 128-140. [CrossRef]

28. Svensson, K.A.; Hao, J.; Bruns, R.F. Positive allosteric modulators of the dopamine $\mathrm{D}_{1}$ receptor: A new mechanism for the treatment of neuropsychiatric disorders. Adv. Pharmacol. 2019, 86, 273-305. [CrossRef]

29. Luderman, K.D.; Jain, P.; Free, R.B.; Conroy, J.L.; Aubé, J.; Sibley, D.R.; Frankowski, K.J. Development of pyrimidone D $_{1}$ dopamine receptor positive allosteric modulators. Bioorg. Med. Chem. Lett. 2021, 31, 127696. [CrossRef]

30. Sun, B.; Feng, D.; Chu, M.L.H.; Fish, I.; Lovera, S.; Sands, Z.A.; Kelm, S.; Valade, A.; Wood, M.; Ceska, T.; et al. Crystal structure of dopamine D1 receptor in complex with G protein and a non-catechol agonist. Nat. Commun. 2021, 12, 3305. [CrossRef]

31. Sibley, D.R.; Luderman, K.D.; Free, R.B.; Shi, L. Novel Cryo-EM structures of the D1 dopamine receptor unlock its therapeutic potential. Signal Transduct. Target. Ther. 2021, 6, 205. [CrossRef] [PubMed]

32. Zhuang, Y.; Xu, P.; Mao, C.; Wang, L.; Krumm, B.; Zhou, X.E.; Huang, S.; Liu, H.; Cheng, X.; Huang, X.P.; et al. Structural insights into the human $\mathrm{D}_{1}$ and $\mathrm{D}_{2}$ dopamine receptor signaling complexes. Cell 2021, 184, 931-942. [CrossRef] [PubMed]

33. Wilbraham, D.; Biglan, K.M.; Svensson, K.A.; Tsai, M.; Kielbasa, W. Safety, tolerability, and pharmacokinetics of Mevidalen (LY3154207), a centrally acting dopamine $\mathrm{D}_{1}$ receptor-positive allosteric modulator $\left(\mathrm{D}_{1} \mathrm{PAM}\right)$, in healthy subjects. Clin. Pharmacol. Drug Dev. 2021, 10, 393-403. [CrossRef]

34. Christopoulos, A.; Kenakin, T. G protein-coupled receptor allosterism and complexing. Pharmacol. Rev. 2002, 54, 323-374. [CrossRef]

35. Wootten, D.; Christopoulos, A.; Sexton, P.M. Emerging paradigms in GPCR allostery: Implications for drug discovery. Nat. Rev. Drug Discov. 2013, 12, 630-644. [CrossRef] [PubMed]

36. Lewis, M.A.; Hunihan, L.; Watson, J.; Gentles, R.G.; Hu, S.; Huang, Y.; Bronson, J.; Macor, J.E.; Beno, B.R.; Ferrante, M.; et al. Discovery of D1 dopamine receptor positive allosteric modulators: Characterization of pharmacology and identification of residues that regulate species selectivity. J. Pharmacol. Exp. Ther. 2015, 354, 340-349. [CrossRef]

37. Leach, K.; Sexton, P.M.; Christopoulos, A. Allosteric GPCR modulators: Taking advantage of permissive receptor pharmacology. Trends Pharmacol. Sci. 2007, 28, 382-389. [CrossRef]

38. Cabellero, A.G.; Croft, A.K.; Nalli, S.M. Remote aromatic stabilization in radical reactions. Tetrahedron Lett. 2008, 49, 3613-3615. [CrossRef]

39. Camps, P.; Font-Bardia, M.; Giménez, S.; Pérez, F.; Solans, X.; Soldevilla, N. (R)- and (S)-3-Hydroxy-4,4-dimethyl-1-phenyl-2pyrrolidinone as chiral auxiliaries in Diels-Alder reactions. Tetrahedron Asymmetry 1999, 10, 3123-3138. [CrossRef]

40. Brocksom, T.J.; Nakamura, J.; Ferreira, M.L.; Brocksom, U. The Diels-Alder reaction: An update. J. Braz. Chem. Soc. 2001, 12, 597-622. [CrossRef]

41. Kagan, H.B.; Riant, O. Catalytic asymmetric Diels Alder reactions. Chem. Rev. 1992, 92, 1007-1019. [CrossRef]

42. Nicolaou, K.C.; Snyder, S.A.; Montagnon, T.; Vassilikogiannakis, G. The Diels-Alder reaction in total synthesis. Angew. Chem. 2002, 41, 1668-1698. [CrossRef]

43. Corey, E.J.; Ensley, H.E. Preparation of an optically active prostaglandin intermediate via asymmetric induction. J. Am. Chem. Soc. 1975, 97, 6908-6909. [CrossRef] [PubMed]

44. Neises, B.; Steglich, W. Simple method for the esterification of carboxylic acids. Angew. Chem. Int. Ed. Engl. 1978, 17, 522-524. [CrossRef]

45. Myers, A.G.; Yang, B.H.; Chen, H.; McKinstry, L.; Kopecky, D.J.; Gleason, J.L. Pseudoephedrine as a practical chiral auxiliary for the synthesis of highly enantiomerically enriched carboxylic acids, alcohols, aldehydes, and ketones. J. Am. Chem. Soc. 1997, 119, 6496-6511. [CrossRef] 
46. Kim, B.R.; Lee, H.-G.; Kang, S.-B.; Sung, G.H.; Kim, J.-J.; Park, J.K.; Lee, S.-G.; Yoon, Y.-J. tert-Butoxide-assisted amidation of esters under green conditions. Synthesis 2012, 44, 42-50. [CrossRef]

47. Poll, T.; Sobczak, A.; Hartmann, H.; Helmchen, G. Diastereoface-discriminative metal coordination in asymmetric synthesis: D-pantolactone as practical chiral auxiliary for Lewis acid catalyzed Diels-Alder reactions. Tetrahedron Lett. 1985, 26, 3095-3098. [CrossRef]

48. Miyaji, K.; Ohara, Y.; Takahashi, Y.; Tsuruda, T.; Arai, K. Synthesis of Corey lactone via highly stereoselective asymmetric Diels-Alder reaction. Tetrahedron Lett. 1991, 32, 4557-4560. [CrossRef]

49. Helmchen, G.; Ihrig, K.; Schindler, H. EPC-syntheses via asymmetric Diels-Alder reactions/retro Diels-Alder reactions I: (R)- and $(S)$-matsutake alcohol. $(R)$ - and (S)-sarcomycin methyl ester. Tetrahedron Lett. 1987, 28, 183-186. [CrossRef]

50. Pelayo, C.; Diego, M.-T. Synthesis and applications of (R)- and (S)-pantolactone as chiral auxiliaries. Curr. Org. Chem. 2004, 8 , 1339-1380. [CrossRef]

51. Manickam, G.; Sundararajan, G. Asymmetric Diels-Alder and ene reactions promoted by a Ti(IV) complex bearing a C2-symmetric tridentate ligand. Tetrahedron Asymmetry 1999, 10, 2913-2925. [CrossRef]

52. Jiang, L.I.; Collins, J.; Davis, R.; Lin, K.M.; DeCamp, D.; Roach, T.; Hsueh, R.; Rebres, R.A.; Ross, E.M.; Taussig, R.; et al. Use of a CAMP BRET sensor to characterize a novel regulation of cAMP by the sphingosine 1-phosphate/G13 pathway. J. Biol. Chem. 2007, 282, 10576-10584. [CrossRef]

53. Canals, M.; Lane, J.R.; Wen, A.; Scammells, P.J.; Sexton, P.M.; Christopoulos, A. A Monod-Wyman-Changeux mechanism can explain G protein-coupled receptor (GPCR) allosteric modulation. J. Biol. Chem. 2012, 287, 650-659. [CrossRef]

54. Rodríguez, J.B.; Markey, S.P.; Ziffer, H. Preparation of 2(R) and 2(S) methyl-2-methylglycerates. Tetrahedron Asymmetry 1993, 4, 101-108. [CrossRef]

55. Xu, X.; Feng, S.; Zhu, Y.; Li, H.; Shen, X.; Zhang, C.; Bai, J.; Zhang, L. Stereospecific radical polymerization of optically active (S)-N-(2-hydroxy-1-phenylethyl) methacrylamide catalyzed by Lewis acids. Eur. Polym. J. 2013, 49, 3673-3680. [CrossRef]

56. Motulsky, H.J.C.; Christopoulos, A. Fitting Models to Biological Data Using Linear and Nonlinear Regression: A Practical Guide to Curve Fitting; GraphPad Software, Inc.: San Diego, CA, USA, 2003.

57. Keov, P.; López, L.; Devine, S.M.; Valant, C.; Lane, J.R.; Scammells, P.J.; Sexton, P.M.; Christopoulos, A. Molecular mechanisms of bitopic ligand engagement with the M(1) muscarinic acetylcholine receptor. J. Biol. Chem. 2014, 289, 23817-23837. [CrossRef]

58. Black, J.W.; Leff, P.; Shankley, N.P.; Wood, J. An operational model of pharmacological agonism: The effect of E/[A] curve shape on agonist dissociation constant estimation. Br. J. Pharmacol. 1985, 84, 561-571. [CrossRef]

59. Sibley, D.R.; Creese, I. Regulation of ligand binding to pituitary D-2 dopaminergic receptors. Effects of divalent cations and functional group modification. J. Biol. Chem. 1983, 258, 4957-4965. [CrossRef]

60. Christopoulos, A. Assessing the distribution of parameters in models of ligand-receptor interaction: To log or not to log. Trends Pharmacol. Sci. 1998, 19, 351-357. [CrossRef] 